\title{
Palaeolatitudinal distribution of lithologic indicators of climate in a palaeogeographic framework
}

\author{
WENCHAO CAO*†, SIMON WILLIAMS*, NICOLAS FLAMENT $\$$, \\ SABIN ZAHIROVIC*, CHRISTOPHER SCOTESE \& \& R. DIETMAR MÜLLER*ף \\ *EarthByte Group and Basin GENESIS Hub, School of Geosciences, The University of Sydney, \\ Sydney, NSW 2006, Australia \\ tSchool of Earth and Environmental Sciences, University of Wollongong, Wollongong, NSW 2522, Australia \\ §Department of Earth \& Planetary Sciences, Northwestern University, Evanston, IL 60208, USA \\ ףSydney Informatics Hub, The University of Sydney, Sydney, NSW 2006, Australia
}

(Received 24 September 2017; accepted 22 January 2018)

\begin{abstract}
Whether the latitudinal distribution of climate-sensitive lithologies is stable through greenhouse and icehouse regimes remains unclear. Previous studies suggest that the palaeolatitudinal distribution of palaeoclimate indicators, including coals, evaporites, reefs and carbonates, has remained broadly similar since the Permian period, leading to the conclusion that atmospheric and oceanic circulation control their distribution rather than the latitudinal temperature gradient. Here we revisit a global-scale compilation of lithologic indicators of climate, including coals, evaporites and glacial deposits, back to the Devonian period. We test the sensitivity of their latitudinal distributions to the uneven distribution of continental areas through time and to global tectonic models, correct the latitudinal distributions of lithologies for sampling- and continental area-bias, and use statistical methods to fit these distributions with probability density functions and estimate their high-density latitudinal ranges with $50 \%$ and $95 \%$ confidence intervals. The results suggest that the palaeolatitudinal distributions of lithologies have changed through deep geological time, notably a pronounced poleward shift in the distribution of coals at the beginning of the Permian. The distribution of evaporites indicates a clearly bimodal distribution over the past $400 \mathrm{Ma}$, except for Early Devonian, Early Carboniferous, the earliest Permian and Middle and Late Jurassic times. We discuss how the patterns indicated by these lithologies change through time in response to plate motion, orography, evolution and greenhouse/icehouse conditions. This study highlights that combining tectonic reconstructions with a comprehensive lithologic database and novel data analysis approaches provide insights into the nature and causes of shifting climatic zones through deep time.
\end{abstract}

Keywords: palaeolatitudinal distribution, palaeoclimate lithologic indicators, atmospheric $\mathrm{CO}_{2}$, palaeogeography, plate tectonic reconstructions, statistical analysis

\section{Introduction}

The palaeolatitudinal distribution of climate-sensitive lithologic deposits is important for understanding past climates (Gordon, 1975; Evans, 2006; Boucot, Chen \& Scotese, 2013), reconstructing palaeogeographies (Ronov, Khain \& Seslavinsky, 1984; Ronov, Khain \& Balukhovsky, 1989; Scotese 2001, 2004; Golonka et al. 2006; Blakey, 2008) and providing constraints for climate modelling (Boucot \& Gray, 2001; Craggs, Valdes \& Widdowson, 2011) and plate motion histories (Scotese \& Barrett, 1990; Witzke, 1990). However, the past distribution of climate-sensitive lithologies remains poorly understood, especially in deep geological times. Latitudinal distribution patterns of palaeoclimate indicators have been considered broadly stable since the Permian, leading to an interpretation that atmospheric and oceanic circulation control their distribution rather than equator-to-pole temperature gradients (Ziegler et al. 2003). A global

†Author for correspondence: wenchao.cao@sydney.edu.au palaeomagnetic compilation of Earth's basin-scale evaporite records suggests that evaporite palaeolatitudes have varied to some degree over the past 2 billion years, with a relatively large difference between Cenozoic-Mesozoic times (a mean palaeolatitude of $23 \pm 4^{\circ}$ ) and Devonian-Ediacaran times (a mean palaeolatitude of $14 \pm 2^{\circ}$ ) (Evans, 2006). In addition, previous studies have rarely considered the effect of the uneven distribution of continental areas through time (Vilhena \& Smith, 2013) and the implications of applying different global tectonic reconstruction models (Scotese \& Barrett, 1990; Ziegler et al. 2003) on latitudinal distribution of climate indicators.

In order to better understand the latitudinal distribution patterns of climate-sensitive lithologies and the associated climate change, we revisit a globalscale lithologic compilation of coals, evaporites and glacial deposits, with our analysis extending back to the Devonian period $(\sim 400 \mathrm{Ma}$ ago). We test the sensitivity of their latitudinal distribution to uneven distribution of continental areas through time and to reconstruction models, and then quantify their 
Table 1. Time division of the climate-sensitive lithologic indicators of Boucot, Chen \& Scotese (2013) using the 2016 timescale of the International Commission on Stratigraphy (ICS2016). The reconstruction age is the rounded-off middle age of each time interval.

\begin{tabular}{|c|c|c|c|c|c|}
\hline Era & Period & Epoch/Age & Start (Ma) & End (Ma) & Reconstruction age $(\mathrm{Ma})$ \\
\hline \multirow[t]{5}{*}{ Cenozoic } & Neogene & Miocene & 23.0 & 5.3 & 14 \\
\hline & Palaeogene & Oligocene & 33.9 & 23.0 & 28 \\
\hline & & Middle and Late Eocene (Lutetian-Priabonian) & 47.8 & 33.9 & 41 \\
\hline & & Early Eocene (Ypresian) & 56.0 & 47.8 & 52 \\
\hline & & Palaeocene & 66.0 & 56.0 & 61 \\
\hline \multirow[t]{8}{*}{ Mesozoic } & Cretaceous & Late Cretaceous (Coniacian-Maastrichtian) & 89.8 & 66.0 & 78 \\
\hline & & Late Cretaceous (Albian-Turonian) & 113.0 & 89.8 & 101 \\
\hline & & Early Cretaceous (Berriasian-Aptian) & 145.0 & 113.0 & 129 \\
\hline & Jurassic & Late Jurassic & 164 & 145 & 155 \\
\hline & & Early and Middle Jurassic & 201 & 164 & 183 \\
\hline & Triassic & Late Triassic & 237 & 201 & 219 \\
\hline & & Middle Triassic & 247 & 237 & 242 \\
\hline & & Early Triassic & 252 & 247 & 250 \\
\hline Late & Permian & Middle-Late Permian (Artinskian-Lopingian) & 290 & 252 & 271 \\
\hline \multirow[t]{9}{*}{ Palaeozoic } & & Early Permian (Asselian-Sakmarian) & 299 & 290 & 295 \\
\hline & Carboniferous & Late Carboniferous (Kasimovian-Gzhelian) & 307 & 299 & 303 \\
\hline & & Late Carboniferous (Bashkirian-Moscovian) & 323 & 307 & 315 \\
\hline & & Early Carboniferous (Serpukhovian) & 331 & 323 & 327 \\
\hline & & Early Carboniferous (Tournaisian-Visean) & 359 & 331 & 345 \\
\hline & Devonian & Late Devonian & 383 & 359 & 371 \\
\hline & & Middle Devonian (Givetian) & 388 & 383 & 386 \\
\hline & & Middle Devonian (Eifelian) & 393 & 388 & 391 \\
\hline & & Early Devonian & 419 & 393 & 406 \\
\hline
\end{tabular}

distribution patterns with corrections of samplingand continental area-bias, using Significant Zero crossings of the derivative (SiZer) of Chaudhuri \& Marron (1999) to obtain the best-fitting probability density functions and Highest Density Regions (HDR) of Hyndman (1996) to compute $50 \%$ and $95 \%$ confidence intervals. The shifting latitudinal distribution patterns reflect climate change associated with hu$\mathrm{mid} /$ arid, precipitation/evaporation or cold/warm climatic conditions. To understand the mechanism, we compare the trends of latitudinal distribution patterns of these palaeoclimate deposits with the atmospheric $\mathrm{CO}_{2}$ evolution (Foster, Royer \& Lunt, 2017) and tropic mountain range areas derived from the palaeogeographic maps (Golonka et al. 2006; Cao et al. 2017) over time, as increased silicate weathering rates associated with tropical mountain uplift lead to a decrease in atmospheric $\mathrm{CO}_{2}$ concentration and this may initiate glaciation (Tabor \& Poulsen, 2008; Montañez \& Poulsen, 2013; Goddeŕis et al. 2017; Swanson-Hysell \& Macdonald, 2017).

\section{Data and global plate tectonic models}

We use a dataset of climate-sensitive lithologies, including coals, evaporites and glacial deposits (tillites, dropstones and glendonites), based on a comprehensive global-scale compilation (Boucot, Chen \& Scotese, 2013). This compilation records and evaluates various types of climatically sensitive lithologic deposits, including coal, cyclothems, laterite, bauxite, lateritic manganese, oolitic ironstone, kaolinite, glendonite, tillites, dropstones, calcretes, evaporites, clay minerals, palms, mangroves and crocodilians, based on a comprehensive literature review. It covers geological times from the Cambrian period to the Miocene epoch. Each data point includes a reference source and geographic location. In order to analyse the effect of global climate change on the latitudinal distribution patterns of climate-sensitive lithologies, we use recorded occurrences of coals, (mostly marine) evaporites, and glacial deposits (a combination of tillites, dropstones and glendonites) in this study, as distributions of other lithologies included in the database are less reliable latitude indicators. For instance, the record of palms, mangroves and crocodilians suffers from sampling bias as they are mostly collected from middle-high latitudes, while sample sizes are small for laterites and oolitic ironstones.

The dataset used in this study covers Devonian to Miocene times and is divided into 23 time intervals at the scale of geological stages (Table 1). The time range that we assign to each data point is entirely derived from the time ranges that Boucot, Chen \& Scotese (2013) used to draw the maps, and we use the middle ages of these time intervals to determine the reconstruction times (Table 1). We use modern peats (as they may eventually become coals), evaporites and glacial sediments (tillites and 'glacio-marine' beds) from Ziegler et al. (2003) for reference. Coals and peats are generally considered as indicators of terrestrial humidity, reflecting climatic regimes in which precipitation exceeds or is equal to evaporation (Parrish, Ziegler \& Scotese, 1982; Hallam, 1985; McCabe \& Parrish, 1992; Price, Sellwood \& Valdes, 1995). Evaporites are formed in climatic conditions where evaporation exceeds the combined effects of precipitation, marine or river influx, and runoff (Craggs, Valdes \& Widdowson, 2011), yet, they may occur in temperate regions (Boucot, Chen \& Scotese, 2013). Tillites, dropstones and glendonites in the dataset are glacial or glacial-origin deposits indicating cold climate, generally due to high 


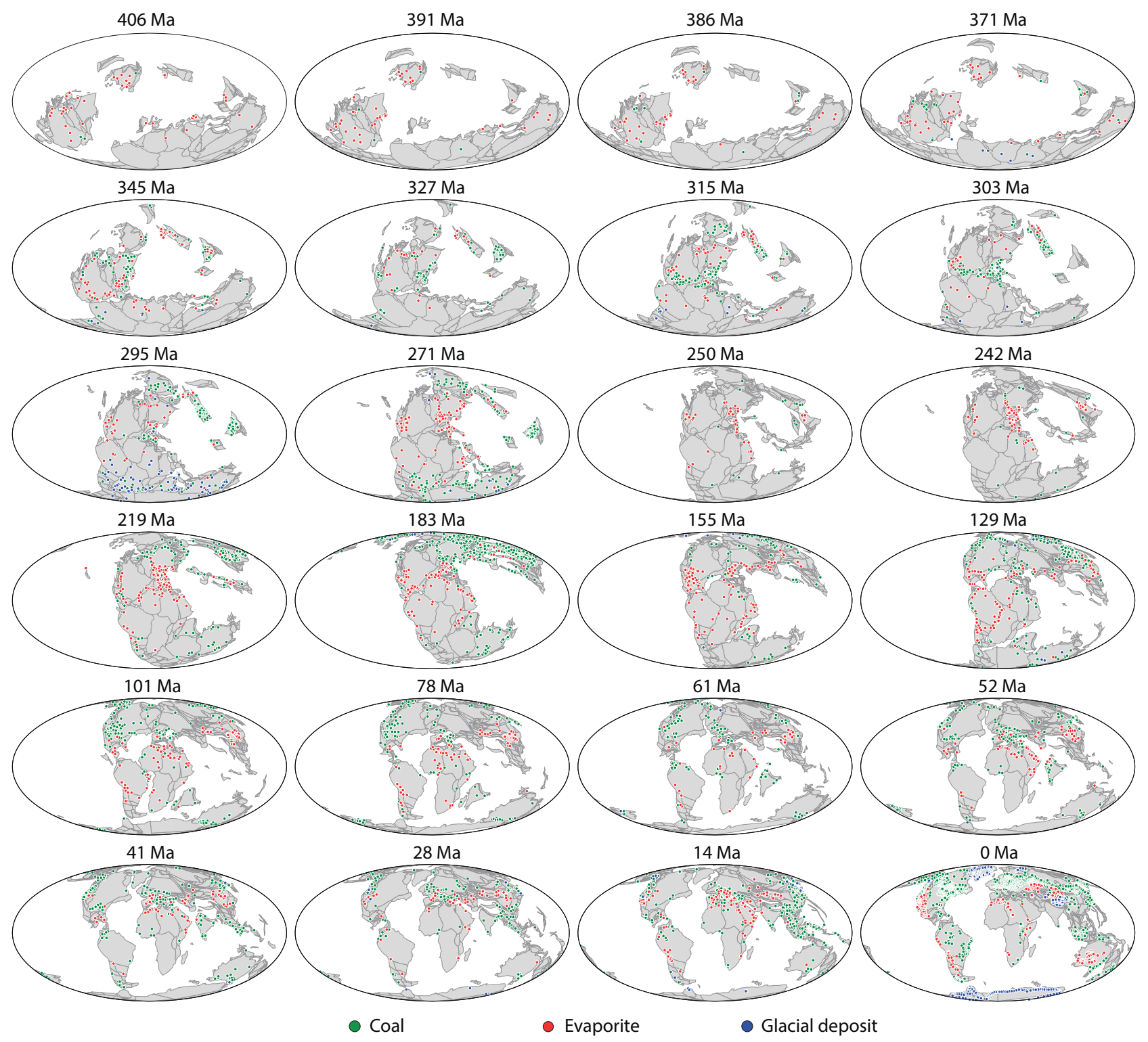

Figure 1. (Colour online) Locations of climate-sensitive lithologic data reconstructed using the plate motion model of Matthews et al. (2016): coals (green), evaporites (red) and glacial deposits (blue) since the Early Devonian (Ziegler et al. 2003; Boucot, Chen \& Scotese, 2013). Ages at the top of each panel are reconstruction ages according to the timescale described in Table 1.

latitudes, but some could be related to high elevations (Boucot, Chen \& Scotese, 2013).

The climatically sensitive lithologic deposits are distributed unevenly over different time intervals (Figs 1, 2). There are very few records of coals in the Devonian period (Figs 1, 2), with coals largely occurring in the Late Devonian stratigraphies (Boucot, Chen $\&$ Scotese, 2013). Yet a large number of coal records appear in Carboniferous, Permian, Late Triassic, Early Jurassic and Neogene times (Figs 1, 2a). Evaporites have relatively uniform richness over most of the time intervals, except in Devonian, Late Carboniferous, Early Permian and Palaeogene times (Figs 1, $2 \mathrm{~b}$ ), whereas, glacial deposit records are relatively rare and sparse over time (Figs 1, 2c) due to the dominance of greenhouse conditions in the Phanerozoic (Hay, 2016).
In this study, we primarily use the global plate tectonic model of Matthews et al. (2016) to reconstruct the lithologic data points back in time from presentday geographic locations. This tectonic model represents a combination of a tectonic model for Mesozoic and Cenozoic times (230-0 Ma) (Muller et al. 2016) and a tectonic model for Palaeozoic times (410 $250 \mathrm{Ma})$ (Domeier \& Torsvik, 2014), with a number of changes required to enable a smooth merging of the models as described by Matthews et al. (2016). It is a relative plate motion model that is ultimately tied to Earth's spin axis through an absolute reference frame (Matthews et al. 2016). We removed the true polar wander correction from the original absolute plate motion model (Domeier \& Torsvik, 2014) to tie the relative rotations to a palaeomagnetic reference frame. Therefore, the tectonic reconstruction better reflects 

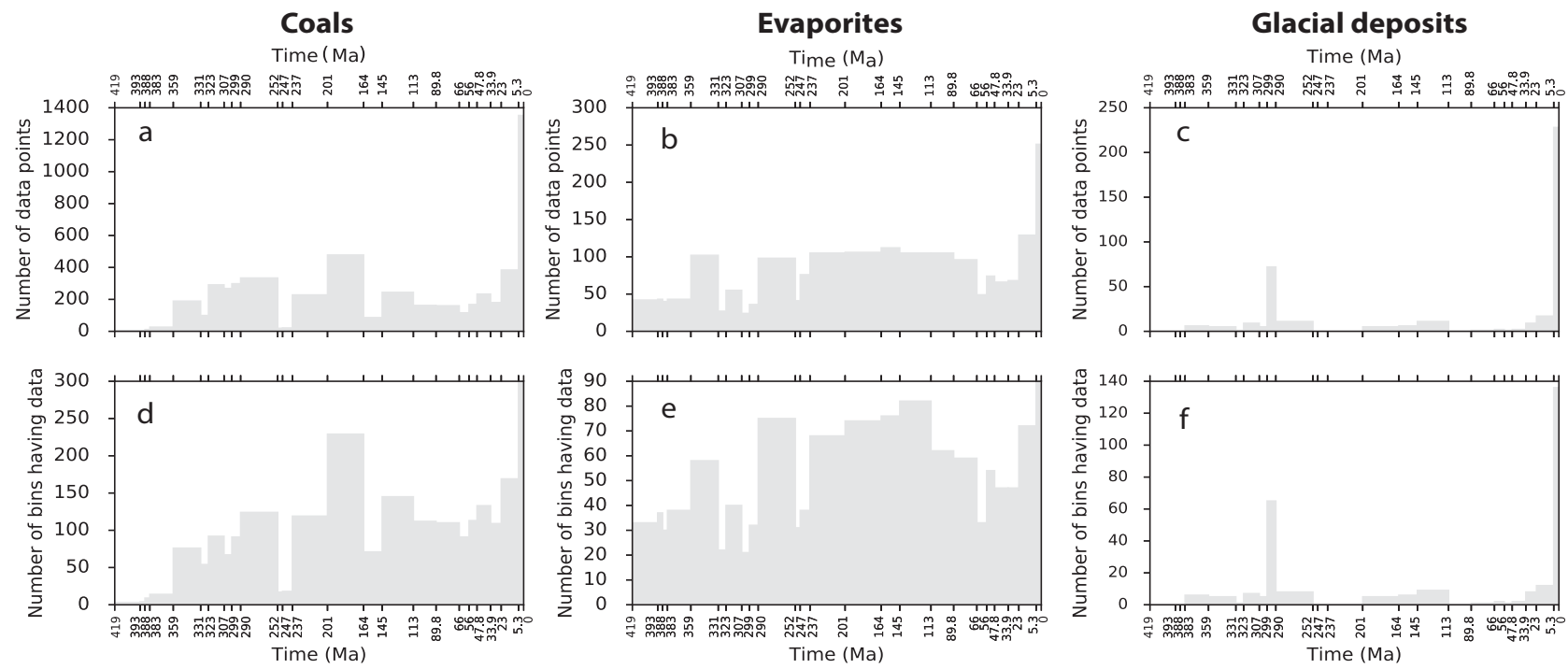

Figure 2. (a, b, c) Sum of data points of coals, evaporites and glacial deposits at each time interval since the Devonian period. (d, e, f) Sum of resampled data points for coals, evaporites and glacial deposits at each time interval since the Devonian period.

the true palaeolatitudinal distribution of palaeoclimate indicators (van Hinsbergen et al. 2015).

In order to test the sensitivity of the palaeolatitudinal distribution of climate-sensitive deposits to the choice of reconstruction model, except for the plate motion model of Matthews et al. (2016), we use two alternative reconstruction models of Scotese (2008) and Golonka (2007) which are both based on the reconstruction of Scotese (2004). The reconstruction model of Golonka (2007) uses palaeomagnetic data to constrain the palaeolatitudinal positions of continents and rotation of plates, and hot spots, where applicable, are used as reference points to calculate palaeolongitudes. A version of this model that includes an updated absolute reference frame is described in Wright et al. (2013), and the model is available in the supplementary materials of Wright et al. (2013). The reconstruction model of Scotese (2008) uses palaeomagnetic reference frames for 410-250 Ma (Ziegler et al. 1979) and 250-100 Ma (Ziegler, Scotese \& Barrett, 1983), and a hotspot reference frame for $100-0 \mathrm{Ma}$ (Müler, Royer \& Lawver, 1993).

\section{Methods}

We first reconstructed the lithologic data for coals, evaporites and glacial deposits from their modern locations to ancient locations in geological time (Fig. 1) using the global plate motion model of Matthews et al. (2016). Due to the inconsistency of age assignments between some lithologic data and "underlying" terrane polygons, leading to unexpected reconstructed locations of these lithologic data, we only considered the data points whose time ranges of existence were within the time span and present-day spatial extent of the underlying terrane. We next binned the data points using a $5^{\circ} \times 5^{\circ}$ mesh of the global surface, following Ziegler et al. (2003) (Fig. 3b). Each bin contained a a

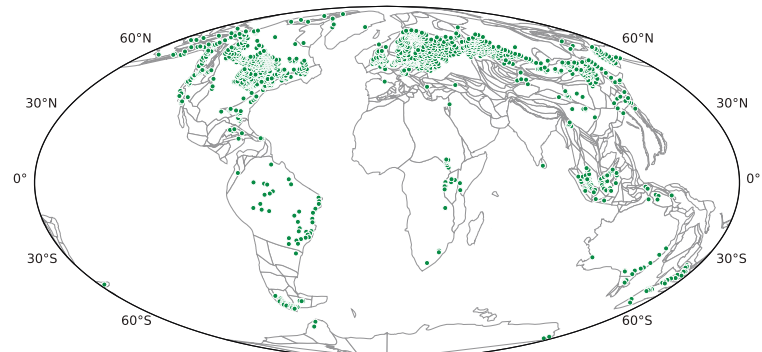

b
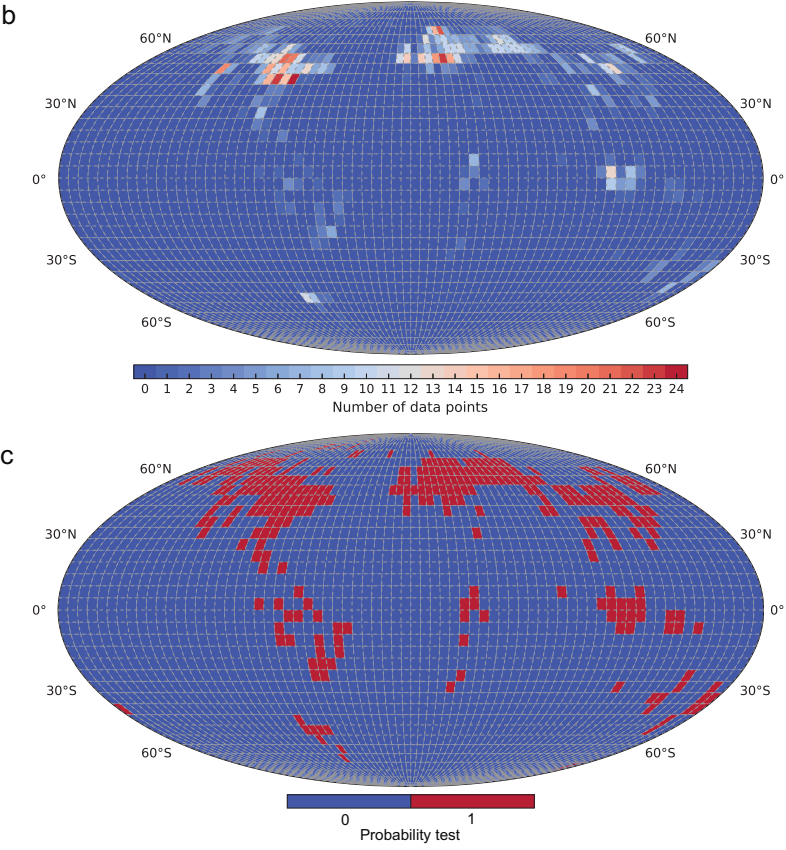

Figure 3. (Colour online) (a) Present-day locations of modern global peats (green points) from Ziegler et al. (2003). Grey polygons are modern terrane geometries. (b) Distribution of modern peat points binned using a $5^{\circ} \times 5^{\circ}$ mesh of the global surface. (c) Distribution of resampled modern peat points (red: bins containing at least one data point; blue: bins containing no data points). 
variable number of data points or none; for example, a bin could contain 0-24 data point(s) for modern peats at present-day coordinates (Fig. 3b). The recorded data points were unevenly distributed spatially (Fig. 3a, b), largely due to sampling bias. To remove the bias, we resampled the data by collapsing all the samples into a single value for each bin: 1 where data existed (Fig. 3c, red bins), and 0 where there were no data points (Fig. 3c, blue bins). We subsequently summed up the numbers of resampled data in each $5^{\circ}$ latitudinal strip (Fig. 4b). These steps significantly reduced the numbers of data points considered per latitudinal strip (compare the $y$-axis of Fig. $4 a, b$ ).

Plate tectonic motion (Golonka, 2007; Scotese, 2008; Matthews et al. 2016) leads to a biased distribution of lithologic deposits on Earth. Latitude bands containing more continental area are more likely to have more lithologic deposits preserved. In an attempt to remove this bias, we first calculated the continental area covered by each $5^{\circ}$ latitudinal strip at each time interval since the Devonian period (Fig. 4c), using the HEALPix pixelization method that results in equal sampling of data on a sphere (Goŕski et al. 2005) and therefore equal sampling of surface areas. We next corrected the number of resampled lithologic data in a $5^{\circ}$ latitudinal strip using the continental area in the same strip to remove the bias due to the uneven distribution of continental areas through time. Subsequently, the results were scaled to represent probabilities of data appearing in a $5^{\circ}$ latitudinal strip (Fig. 4d). In order to investigate the palaeolatitudinal zonal patterns of these climate indicators, we combined the data corrected for continental area bias from both hemispheres to form symmetric and composite zonal patterns, and normalized the results in a strip into probabilities with respect to the sum of all the values in the same strip (Fig. 4e). The symmetric zonal patterns erased the differences between the two hemispheres and can be used to indicate the influence of climate change on the distribution of climate-sensitive lithologic deposits (Scotese \& Barrett, 1990; Ziegler et al. 2003).

We used SiZer (SIgnificant ZERo crossing of the derivatives; by Chaudhuri \& Marron, 1999), a data analysis method to identify significant peaks from kernel density estimation to obtain probability density functions of zonal patterns (Fig. 4f, black lines). Instead of trying to find the one bandwidth that provides the closest match to the unknown true density, SiZer looks at the whole range of bandwidths. Peaks and troughs are identified by finding the regions of significant gradient (zero crossings of the derivative; Chaudhuri \& Marron, 1999). In order to identify high-density intervals of distribution of these palaeoclimate indicators, we used the HDR method of Hyndman (1996) to compute the high-density latitude ranges with $50 \%$ (Fig. 4f, grey area) and 95\% (Fig. 4f, light grey area) confidence intervals. HDR is a statistical method for calculating confidence intervals when the sampling distribution has multiple peaks. For discrete-valued distribution, HDR simply consists of those elements of

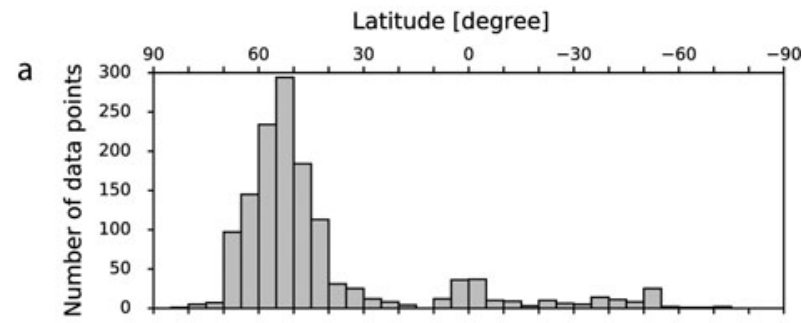

b.
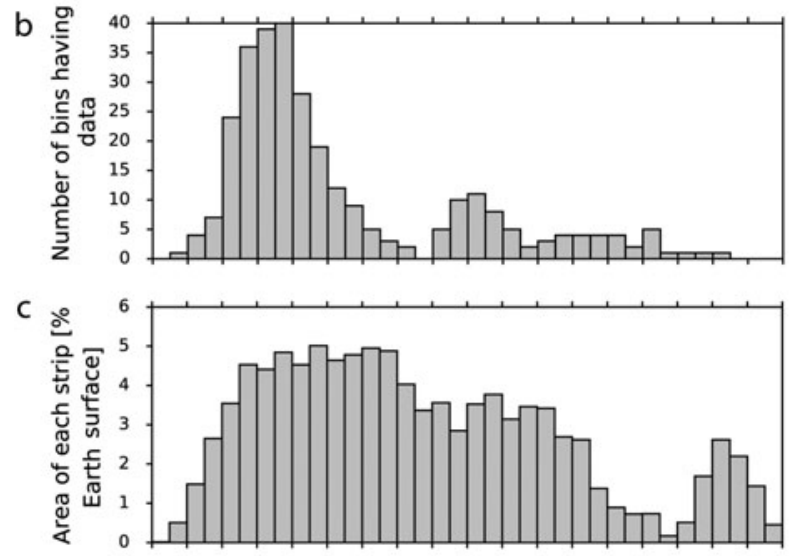

d

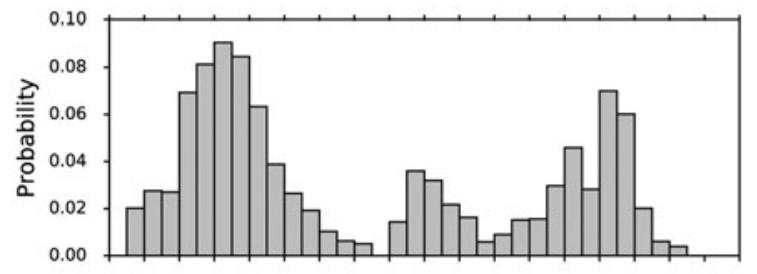

e
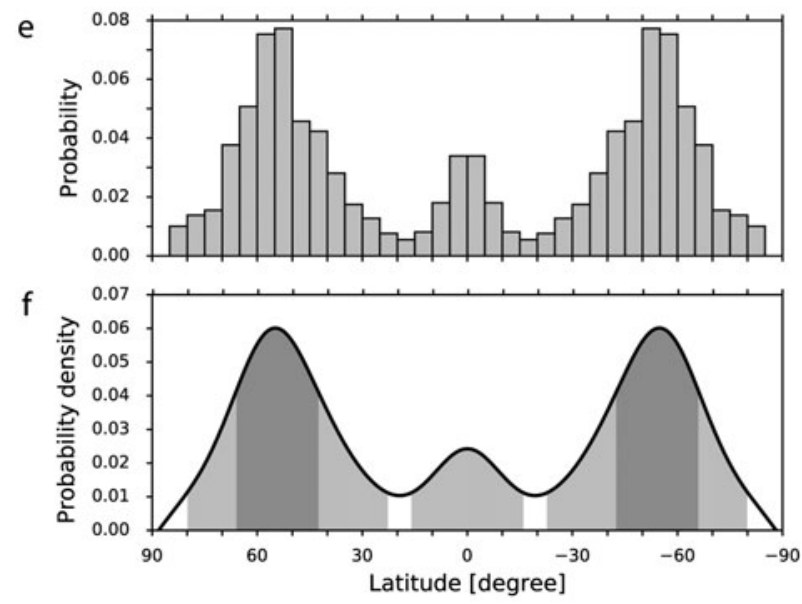

Figure 4. (a) Number of original modern peat points from Ziegler et al. (2003) in each $5^{\circ}$ latitudinal strip. (b) Number of resampled modern peat points in each $5^{\circ}$ latitudinal strip. (c) Modern continental area in each $5^{\circ}$ latitudinal strip as a percentage of total modern continental area. (d) Distribution of resampled modern peat points with continental area bias corrected. (e) Distribution of modern peat points with sampling- and areabiases corrected. The two hemispheres are combined to form a symmetric distribution pattern (also known as zonal pattern; Scotese \& Barrett, 1990; Ziegler et al. 2003). (f) Fitted probability density function (black line) using the method of SiZer from Chaudhuri \& Marron (1999). High-density latitude ranges at confidence intervals of $50 \%$ (grey area) and $95 \%$ (light grey area) using the HDR method of Hyndman (1996). 
the sample space with highest probability (Hyndman, 1996).

\section{Results}

\section{4.a. Palaeolatitudinal distribution of coals, evaporites and} glacial deposits

We counted the original data points for coals (Fig. 5a), evaporites (Fig. 6a) and glacial deposits (Fig. 7a) reconstructed using the plate tectonic model of Matthews et al. (2016) in each $5^{\circ}$ latitudinal strip at each time interval since the Devonian period. Coals are distributed in a wide latitude range from the equator to the poles (Fig. 5a), while evaporites are concentrated between $60^{\circ} \mathrm{N}$ and $60^{\circ} \mathrm{S}$ (Fig. 6a). Glacial deposits generally occur in middle-high latitudes except for a record of glendonites appearing near the equator in the Early Carboniferous (TournaisianVisean) from an outer shelf environment with near- $0{ }^{\circ} \mathrm{C}$ seawater (Brandley \& Krause, 1993a, b, 1994), a record of tillites in the Late Carboniferous (KasimovianGzhelian) and a record of tillites in the Early Permian, both from a high-elevation periglacial environment (Becq-Giraudon, Montenat \& Van den Driessche, 1996) (Fig. 7a). Therefore, these three records (highlighted with question marks in Fig 7) may not be reliable enough to indicate cold climate relevant to latitudinal change.

Generally, more data points of coals (Fig. 5a), evaporites (Fig. 6a) and glacial deposits (Fig. 7a) are sampled from the northern than the southern hemisphere since Pangaea break-up in the Early Jurassic (Ronov, Khain \& Seslavinsky, 1984; Ronov, Khain \& Balukhovsky, 1989; Scotese, 2001, 2004; Golonka et al. 2006; Blakey, 2008). During Early Devonian - Late Triassic time, the numbers of data points of these lithologies in the southern hemisphere exceed those in the northern hemisphere in general, with glacial deposits only occurring in the southern hemisphere in Early Devonian and Carboniferous times (Fig. 7a). This mainly reflects the fact that plate tectonic motions modify the continental configuration through time, which has led to more continental areas in the northern hemisphere since the Early Jurassic (Figs 5c, 8). Continental areas in the northern hemisphere have consistently increased since the Devonian period, while the areas in the southern hemisphere have decreased accordingly (Figs 5c, 8).

After removing the sampling- (Figs 5b, 6b, 7b) and continental area-biases (Figs 5d, 6d, 7d) over the data in each $5^{\circ}$ strip at each time interval, the differences among strips at a time interval are evened out to some degree (for example, compare the $y$-axis of Fig. 5a, b, d). The zonal patterns for coals (Fig. 5e), evaporites (Fig. 6e) and glacial deposits (Fig. 7e) vary considerably over time.

We compute the high-density latitudinal ranges with $50 \%$ and $95 \%$ confidence intervals for coals (Fig. 5f), evaporites (Fig. 6f) and glacial deposits (Fig. 7f), re- spectively, at each time interval. Considering the extent of these $95 \%$ confidence ranges, coals are relatively widely distributed on Earth's surface over the time period of interest, extending from the equator to the poles for many time periods (Fig. 5f, light grey area). Evaporites ( $95 \%$ confidence) are generally concentrated within low-middle latitudes $\left(0-60^{\circ}\right)$ in two hemispheres, with a mean palaeolatitude of $26 \pm 3^{\circ}$ in each hemisphere since the Devonian (Fig. 6f, light grey area). This result is consistent with the mean palaeolatitudes of $23 \pm 4^{\circ}$ during Cenozoic-Mesozoic time and $21 \pm 4^{\circ}$ during Permian-Carboniferous time (both with $95 \%$ confidence), recalculated from palaeolatitudes of a global compilation of large evaporite basins extending back through Proterozoic time (Evans, 2006). Glacial deposits (95\% confidence) occur in Late Devonian, Carboniferous, Permian, Jurassic, Early Cretaceous and Late Palaeogene-modern times (Fig. 7f, light grey area). This is generally consistent with three main Phanerozoic ice ages during Carboniferous-Permian, Late Jurassic - early Cretaceous and Early Eocene-modern times (Frakes, Francis \& Syktus, 1992).

Focusing on $50 \%$ confidence intervals, coal latitudinal belts show strong fluctuation over time (Fig. 5f, dark grey area). They move from the middle latitudes towards the equator during the Devonian, but the original coal deposits in the Devonian are too few to provide much climatological insight (Boucot, Chen \& Scotese, 2013). During the Carboniferous, they are strictly limited within $0-25^{\circ} \mathrm{N}$ and $\mathrm{S}$; however, they separate into two latitudinal belts of $0-10^{\circ}$ and 40 $60^{\circ}$ during the earliest Permian (Asselian-Sakmarian) (Fig. 5f). Subsequently, they undergo a poleward shift until reaching higher latitudes $\left(60-90^{\circ}\right)$ during the Late Jurassic, with a sharp equatorward movement in the Early Triassic and a rapid poleward shift in the Middle Triassic but these may be not reliable as they are based on very few data points (Figs 1, 2a). Starting from the Early Cretaceous, the distributions of coals contract towards the equator until the Miocene when there are two latitudinal belts at $\sim 30-50^{\circ}$ and $\sim 0-15^{\circ}$ on two hemispheres, with a rapid shift towards the equator during the Early Eocene. Modern peats are mainly distributed within $\sim 40-65^{\circ}$ latitudes. Overall, the latitudinal belts determined for coals from probability density curves with $50 \%$ confidence generally occur at low latitudes during Palaeozoic time, middle latitudes during Permian, Triassic and Cenozoic times, and high latitudes during Jurassic and Cretaceous times.

Evaporite latitudinal belts with $50 \%$ confidence (Fig. 6f, grey area) mostly occur at low latitudes $(\sim 0$ $30^{\circ} \mathrm{N}$ and S). They move poleward from the Early Devonian until the Early Carboniferous and then towards the equator until the Late Triassic. Starting from the Middle Triassic, they start to shift poleward until modern times at a mean latitude of $\sim 35^{\circ} \mathrm{N}$ and $\mathrm{S}$, with a short and rapid poleward movement during the early Eocene (Lutetian). 


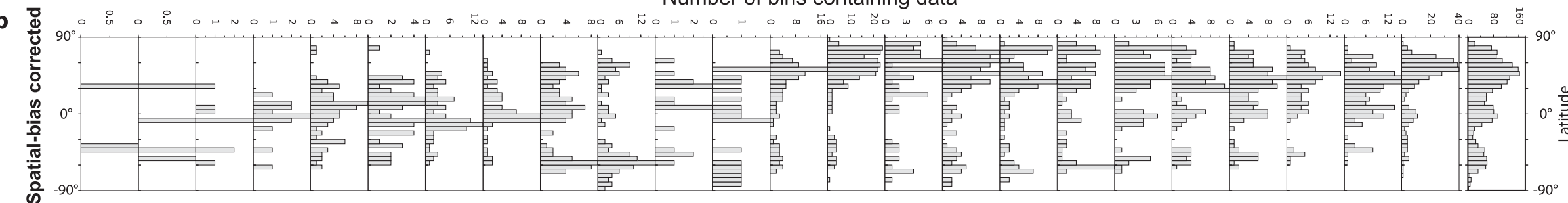

Continental area in each strip [\% total continental area]

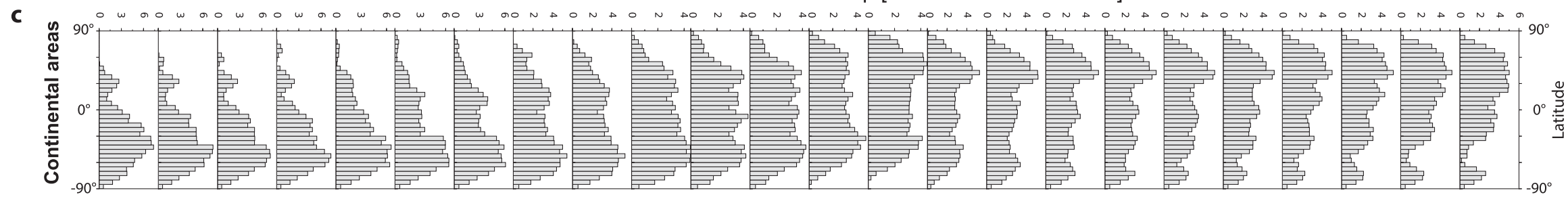

Figure 5. (a) Numbers of original coal points of Boucot, Chen \& Scotese (2013) and Ziegler et al. (2003) reconstructed using the tectonic model of Matthews et al. (2016) in each $5^{\circ}$ latitudinal strip for each time interval since the Devonian period. (b) Number of resampled coal points in each $5^{\circ}$ latitudinal strip for each time interval. (c) Continental area in each $5^{\circ}$ latitudinal strip as a percentage of Earth's surface for each time interval. (d) Distribution of coals with continental area corrected in each $5^{\circ}$ latitudinal strip for each time interval. (e) Symmetric zonal pattern of coals with sampling-

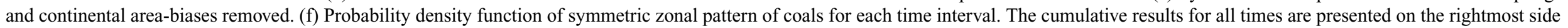
with bold borders. 
Probability

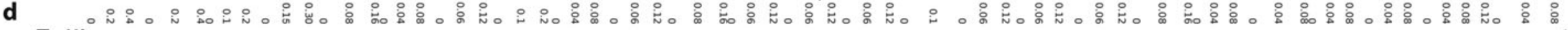

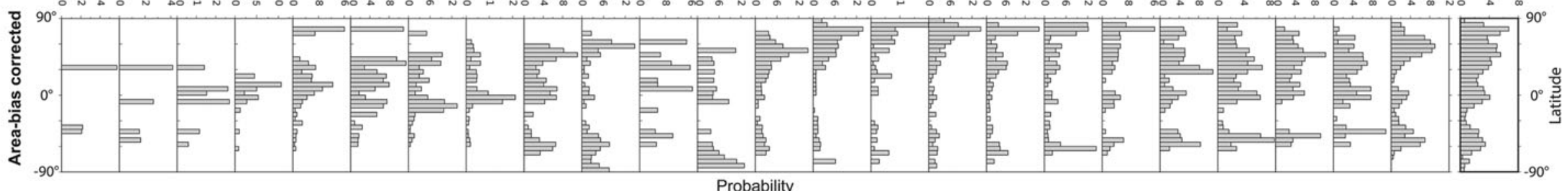

e

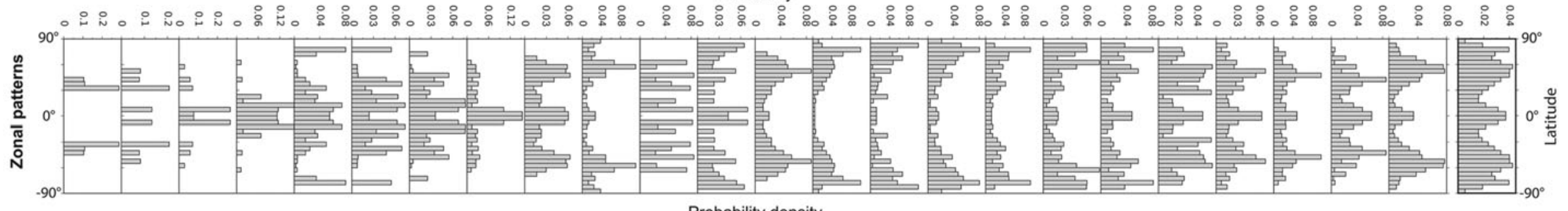
Probability density

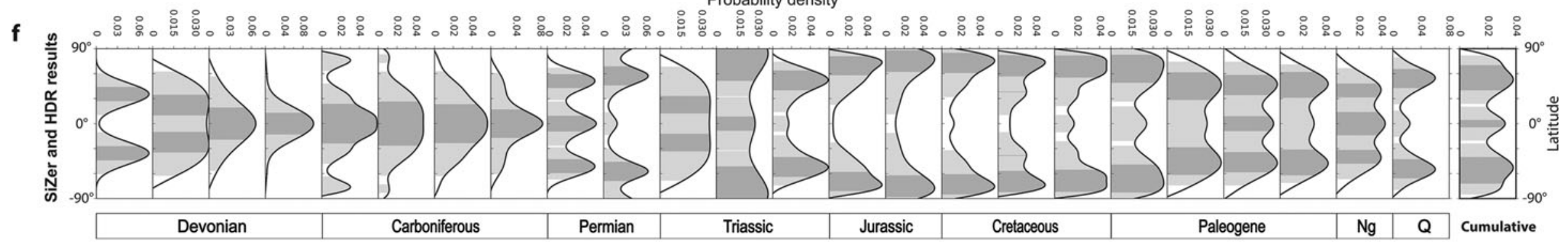


Number of data points

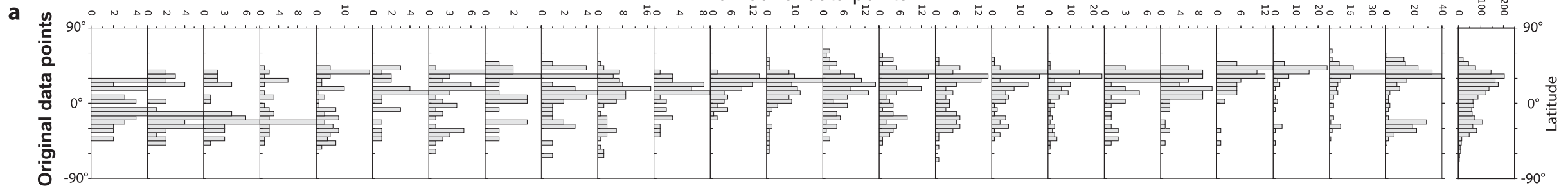

Number of bins containing data

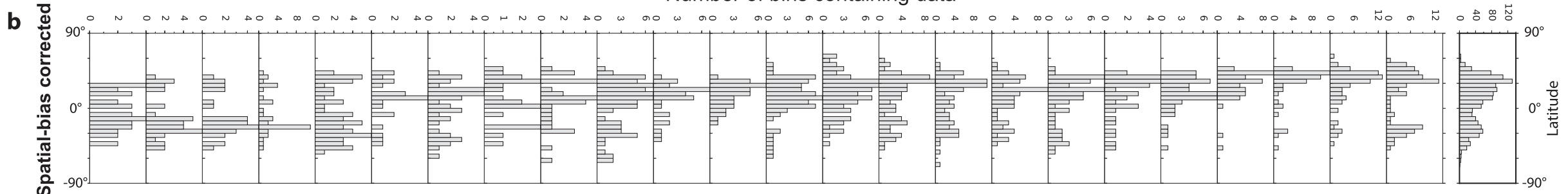

Continental area in each strip [\% total continental area]

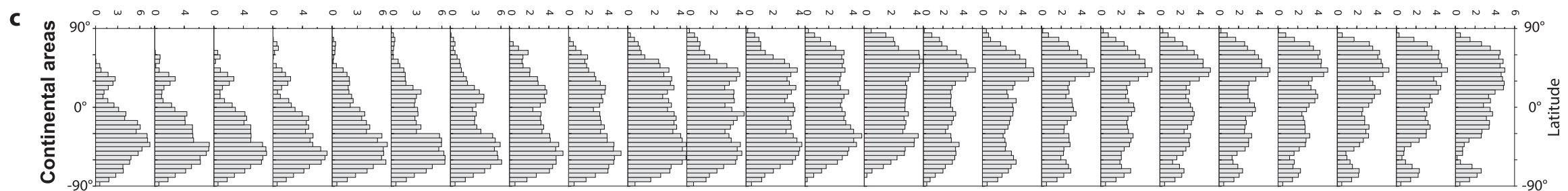

Figure 6. (a) Number of original evaporate points of Boucot, Chen \& Scotese (2013) and Ziegler et al. (2003), reconstructed using the tectonic model of Matthews et al. (2016), in each $5^{\circ}$ latitudinal strip for each time interval since the Devonian period. (b) Number of resampled evaporate points in each $5^{\circ}$ latitudinal strip for each time interval. (c) Continental area in each $5^{\circ}$ latitudinal strip as a percentage of total continental area for each time interval. (d) Distribution of evaporites with continental area corrected in each $5^{\circ}$ latitudinal strip for each time interval. (e) Zonal pattern of evaporites with sampling- and continental area-biases corrected. (f) Probability density function of zonal pattern of evaporites for each time interval. The cumulative results for all times are presented on the rightmost side with bold borders. 
Probability

d

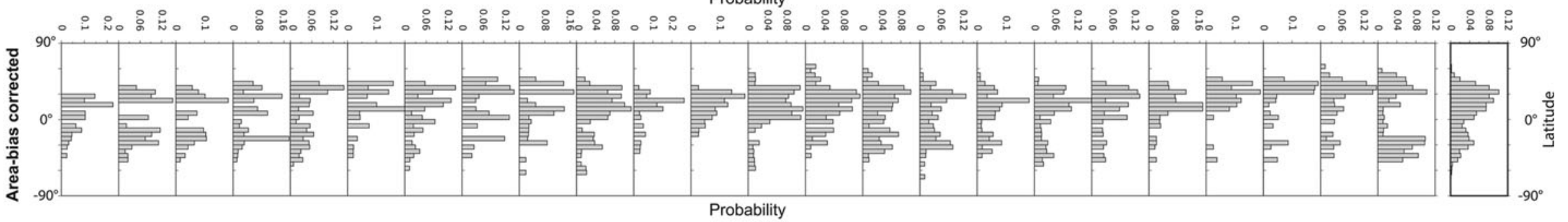

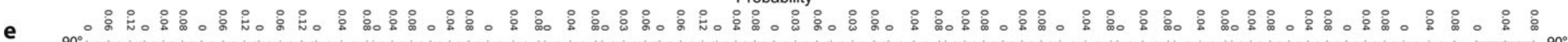

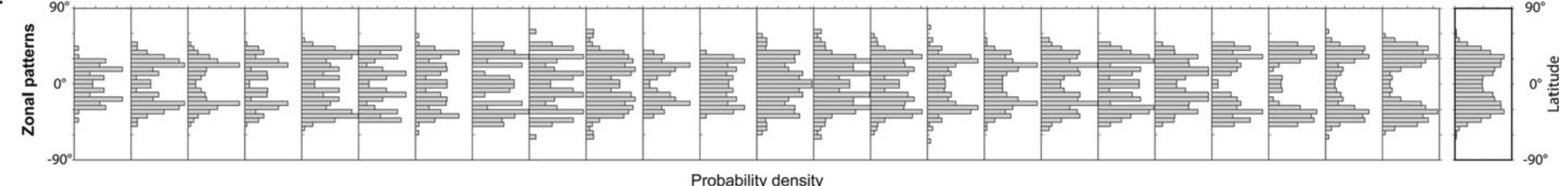

f

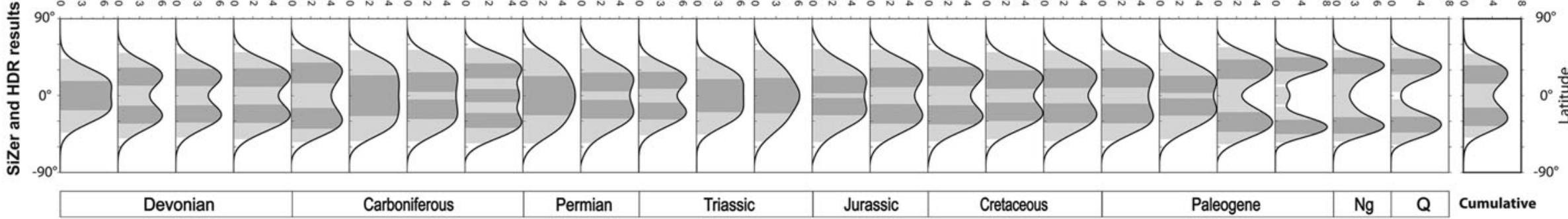

Figure 6. Continued 
Number of bins containing data
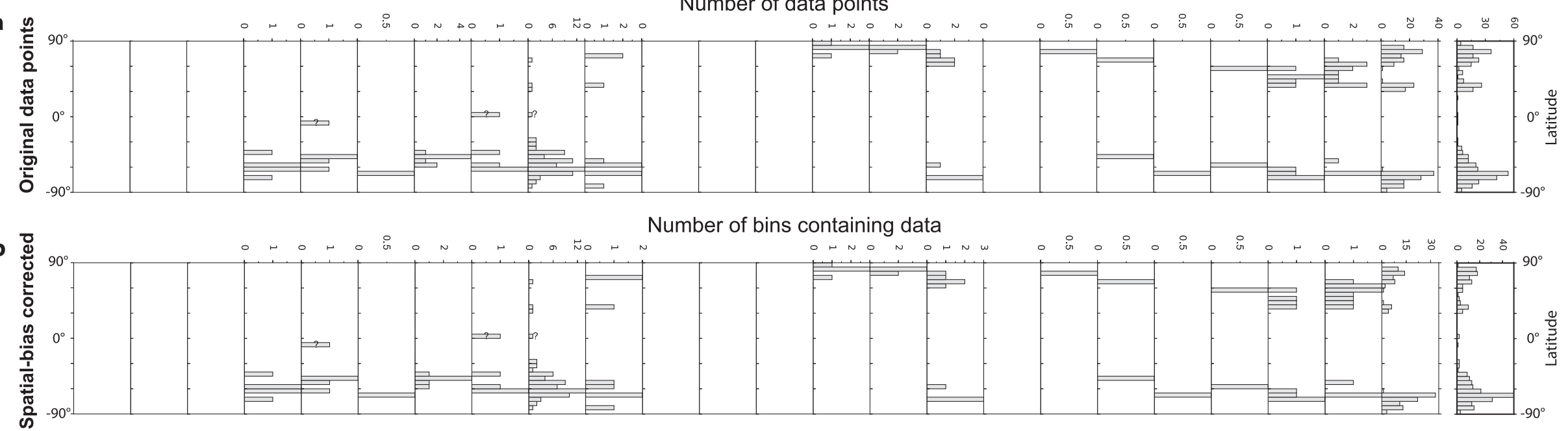

Continental area in each strip [\% total continental area]

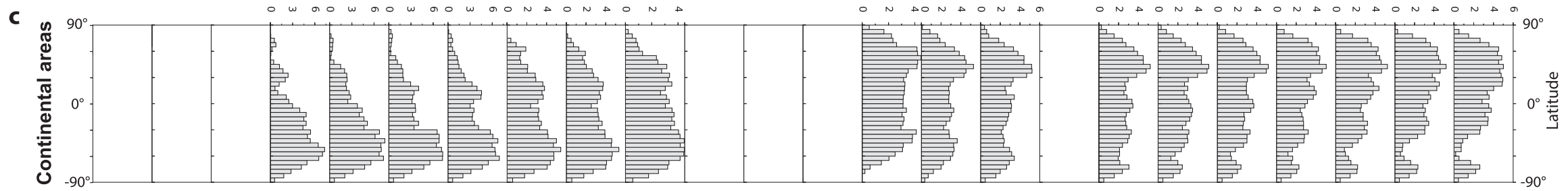

Figure 7. (a) Numbers of original glacial deposit points of Boucot, Chen \& Scotese (2013) and Ziegler et al. (2003) reconstructed using the tectonic model of Matthews et al. (2016) in each $5^{\circ}$ latitudinal strip for each time interval since the Devonian period. (b) Number of resampled glacial deposit points in each $5^{\circ}$ latitudinal strip for each time interval. (c) Continental area in each $5^{\circ}$ latitudinal strip as a percentage of total continental area for each time interval. (d) Distribution of glacial deposit with continental area corrected in each $5^{\circ}$ latitudinal strip for each time interval. (e) Zonal pattern of glacial deposit with sampling- and continental area-biases corrected. (f) Probability density function of zonal pattern of glacial deposits for each time interval. The troughs with a question mark indicate records unlikely to represent latitudinal changes in climate. The cumulative results for all times are presented on the far right with bold borders. 

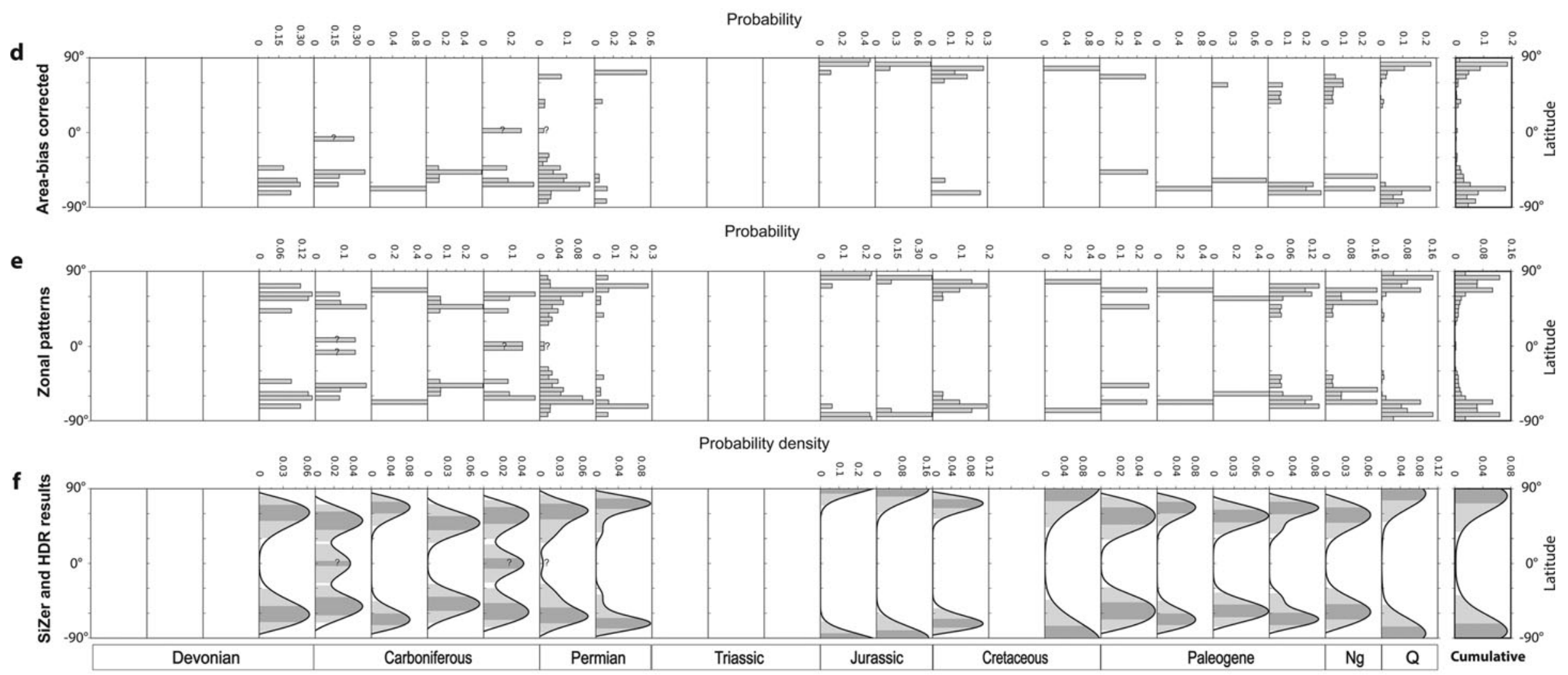


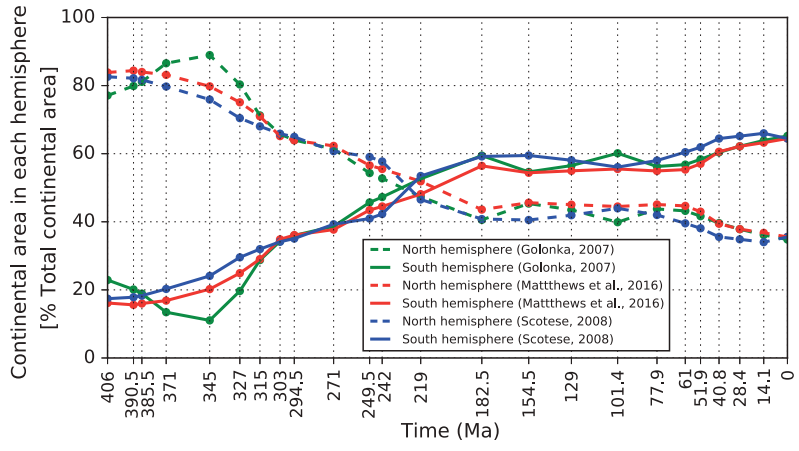

Figure 8. (Colour online) Continental area in the northern and southern hemispheres respectively as a percentage of total continental area at each time interval since the Devonian period.

The trends in how the highest-density latitudes of glacial deposits with $50 \%$ confidence (Fig. 7 f, grey area) shift northwards or southwards are similar to coals, but at higher latitude. They generally concentrate within middle-high latitudes through time (Fig. 7, grey area). They occur at $\sim 50-70^{\circ} \mathrm{N}$ and $\mathrm{S}$ latitudes during the Late Devonian and then move equatorward to middle latitudes $\left(\sim 40-60^{\circ}\right)$ during most of the Carboniferous, with a rapid poleward movement in the Late Mississippian. The Late Pennsylvanian - Early Permian transition is marked by a rapid shift of glacial deposits towards high latitudes. They remain at high latitudes during Jurassic and Cretaceous times, and then move to middle-high latitudes $\left(\sim 50-75^{\circ}\right)$ during Palaeogene and Miocene times. Modern glacial deposits mainly lie near the poles.

\section{4.b. Sensitivity tests}

\section{4.b.1. Assumption of climate symmetry (zonal patterns)}

In order to test the assumption that past climates were zonal and hemispherically symmetric, we investigated the latitudinal distributions of lithologies for each hemisphere independently through time, and estimated their high-density latitudinal belts using the same statistical methods (Supplementary Figs S1 and S2, available at https://doi.org/10.1017/S0016756818000110). At the first order, more lithologic data are distributed on the northern hemisphere over the timeframe, except for late Palaeozoic and Cenozoic times when more glacial deposits formed in the southern hemisphere. The distributions of coals and evaporites in the northern hemisphere (Supplementary Figs S1 and S2, available at https://doi.org/10.1017/S0016756818000110) are similar to the results with data combined over two hemispheres (Fig. 12a, c, further below). This is largely because of the uneven distribution of continental areas through time, leading to a biased distribution of lithologic deposits in the northern hemisphere. Overall, the data distribution warrants combining the two hemispheres in zonal patterns.

\section{4.b.2. Continental area bias}

In order to examine sensitivity of the zonal patterns of these lithologic deposits to continental area bias, we compute the zonal patterns for coals (Fig. 9a), evaporites (Fig. 9b) and glacial deposits (Fig. 9c) for each time interval since the Devonian using the plate motion model of Matthews et al. (2016) with (Fig. 9, blue area) and without (Fig. 9, red) continental area correction, respectively. The distribution patterns of coals using the two approaches are significantly different in Middle Devonian, most of Carboniferous, Early and Middle Triassic, Jurassic, Cretaceous and Early Palaeogene times. During these time periods except the Middle Devonian, the zonal patterns of coals without continental area correction are closer to the equator (Fig. 9, red). This mainly results from the uneven latitudinal distribution of continental areas, with very little to no continental coverage near the poles during these periods (Fig. 5c). Due to relatively small continental coverage near the equator (Fig. $5 \mathrm{c}$ ), the zonal patterns of coals without area correction are closer to the poles during the Middle Devonian (Fig. 9, red).

The uneven distribution of continental areas through time has relatively less impact on the zonal patterns of evaporites (Fig. 9b) and glacial deposits (Fig. 9c). Evaporite zonal patterns are generally identical over time, except during Late Mississippian, Late Pennsylvanian, the earliest Permian, Middle Triassic and late Cretaceous times (Fig. 9b). Due to different continental coverage at different latitudes (Fig. 5c), the area correction leads to more poleward distributions of evaporites during Late Mississippian, Late Pennsylvanian and earliest Permian times but more equatorward during Middle Triassic and late Cretaceous times. With and without area correction, glacial deposit zonal patterns are mostly identical over time, except for most of Permian, Late Palaeogene and modern times, when the area correction results in more poleward distributions, and for Early and Late Mississippian and Late Pennsylvanian times, with more equatorward distributions (Fig. 9c). Overall, latitudinal distributions of coals show stronger sensitivity to uneven distributions of continents than evaporites and glacial deposits, which could be mainly due to coals having a wider latitudinal distribution than evaporites and glacial deposits over time.

\section{4.b.3. Reconstruction model bias}

We use alternative reconstruction models of Scotese (2008) and Golonka (2007) with modifications as described in Wright et al. (2013), in addition to the model of Matthews et al. (2016), to analyse the sensitivity of latitudinal distributions of coals, evaporites and glacial deposits to the reconstruction model. We use the same method described in the Methods section to obtain the probability density functions of the latitudinal distributions for these lithologies over time. The results indicate that the three reconstructions result in 
Probability density

a $\quad 200$

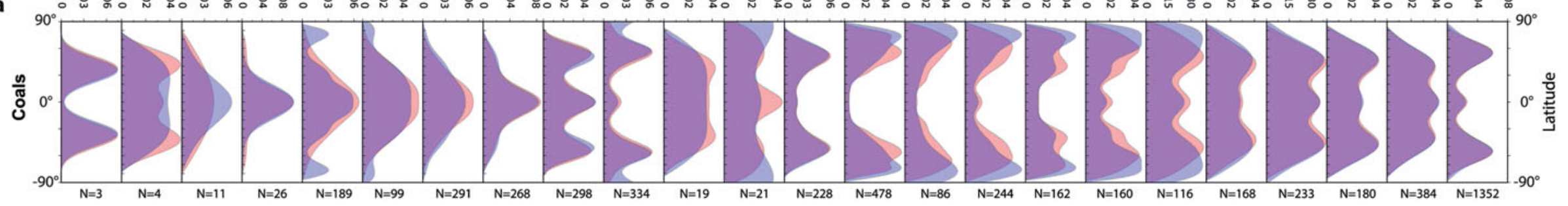

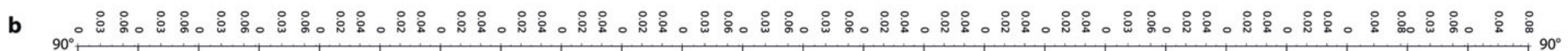
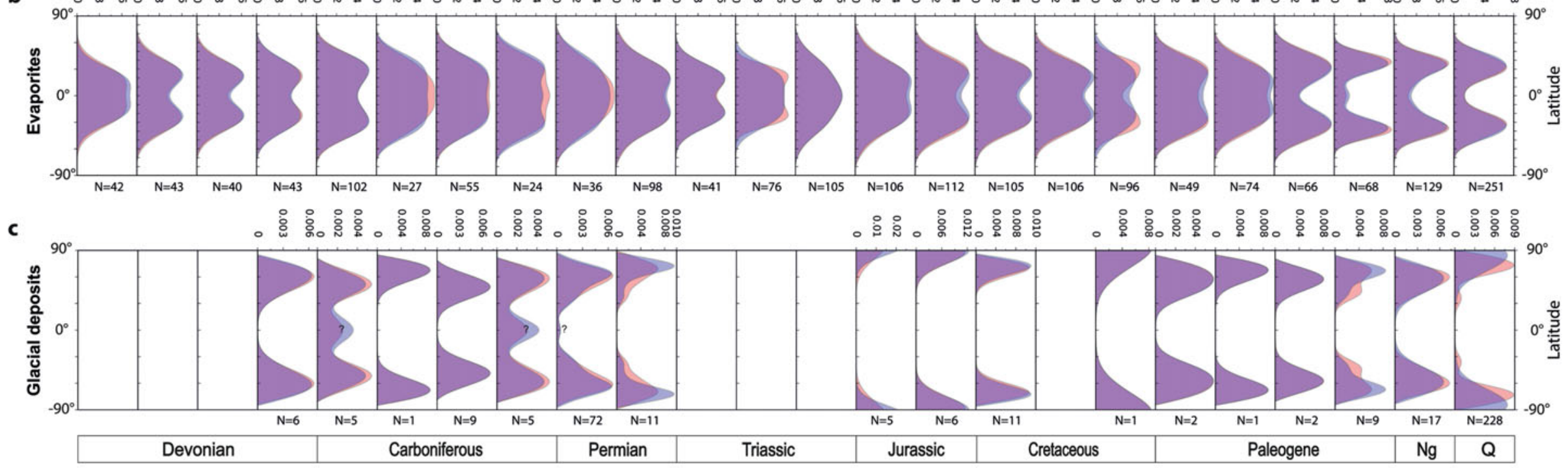

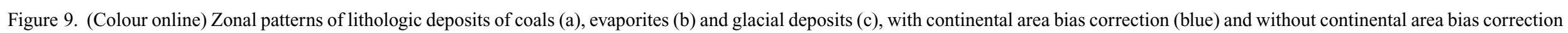

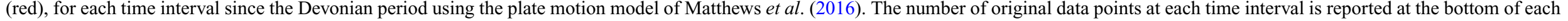
subplot. 
only second-order differences through time (Fig. 10). Differences in the distributions are most pronounced where reconstructed palaeolatitudes differ for blocks that host a large proportion of data points for a given time interval.

The latitudinal distributions of coals reconstructed using the three tectonic models are generally similar over time, except during Early Devonian, Early Carboniferous, the earliest Permian, Middle and Late Palaeogene and Neogene times. In the Early Devonian, the latitudinal distributions of coals using the reconstruction of Golonka (2007) are more northward than those using the other two reconstructions, largely because North America and Eurasia in the model of Golonka (2007) are located further northward than in the other two models during this period (see Supplementary Material available at https://doi. org/10.1017/S0016756818000110). The more poleward location of Africa during the Early Carboniferous in the reconstruction of Matthews et al. (2016) leads to a more poleward distribution of coals. During the earliest Permian, numerous coal deposits occur in North and South China blocks. Their more northward locations in the model of Matthews et al. (2016), taken from the work of Domeier \& Torsvik (2014), result in more occurrences at middle latitudes (see Supplementary Material available at https: //doi.org/10.1017/S0016756818000110). The terranes in the reconstruction of Scotese (2008) are generally further north relative to the other two models during Middle and Late Palaeogene and Neogene times (see Supplementary Material available at https://doi.org/10. 1017/S0016756818000110). This results in more poleward distributions of overall palaeoclimate lithologies (Fig. 10a).

The latitudinal distributions of evaporites among the three reconstructions are very similar since the Devonian (Fig. 10b), except for Early Devonian and Carboniferous times. In the Early Devonian, evaporites are spread further from the equator using the reconstruction of Golonka (2007) than the other two reconstructions, which is mainly due to more northward locations of North America and Eurasia in the model of Golonka (2007). More southward locations of numerous plates in the reconstruction of Golonka (2007) (see Supplementary Material available at https://doi.org/10.1017/S0016756818000110) result in more equatorial distributions of evaporites during the Carboniferous (Fig. 10b).

The latitudinal distributions of glacial deposits are also similar through time among the three considered reconstructions (Fig. 9c), except for the Late Devonian, Early and Middle Mississippian and most of the Permian. During the Late Devonian, more glacial deposits are distributed at high latitudes using the reconstruction of Scotese (2008), mainly due to the more southerly location of South America in this reconstruction than that in the other two reconstructions (see Supplementary Material available at https://doi.org/10. 1017/S0016756818000110). The more equatorial loc- ations of South America and NW Africa in the model of Scotese (2008) lead to more equatorial distributions of glacial deposits during Early and Middle Mississippian times. During most of the Permian period, Antarctica and Australia are closer to the South Pole in the reconstruction of Golonka (2007) (see Supplementary Material available at https://doi.org/10.1017/ S0016756818000110), resulting in more poleward distribution of glacial deposits (Fig. 10c).

\section{4.b.4. Spatial sampling resolution bias}

We compare the use of three different spatial resolutions to bin the original data points to remove the effect of sampling bias on the distribution patterns of these climatically lithologic deposits, using the plate motion model of Matthews et al. (2016), for each time interval since the Devonian period: $10^{\circ}$ (Fig. 11a), $5^{\circ}$ (Fig. 11b) and $2^{\circ}$ (Fig. 11c). The results indicate that there are too few strips containing data points, especially during the Devonian, to be able to obtain much statistical significance using $10^{\circ}$ as the binning size (Fig. 11a). Using $2^{\circ}$ as the binning size results in noisier distributions (Fig. 11c) and a more difficult analysis of distribution patterns. A spatial resolution of $5^{\circ}$ is a good compromise that captures the data distribution yet results in less noise, and follows previous work that aids comparison with our work (Fig. 11b).

\section{Discussion}

\section{5.a. Palaeolatitudinal distribution patterns of lithologic climate indicators over time}

We present the high-density latitudinal ranges in one hemisphere, due to the assumed symmetry of two hemispheres, with $50 \%$ and $95 \%$ confidence intervals for coals (Fig. 12a), evaporites (Fig. 12b) and glacial deposits (Fig. 12c), respectively, at each time interval. We also present the cumulative high-density latitudinal ranges over the entire time period for these lithologies (rightmost panels in Fig. 12a, b, c). Overall, the latitudinal belts determined from probability density curves with $50 \%$ confidence for coals have changed since the Devonian. Some previous studies concluded that the palaeolatitudinal distribution of coals has remained broadly similar since the Permian (Ziegler et al. 2003), whereas we have shown that results for earlier in the Palaeozoic are significantly different from results from the Permian to present (Fig. 12a, b, c). In addition, the temporal division at the scale of geological periods in previous studies did not attempt to resolve variations over shorter time periods, whereas the dataset used in this study is based on a time division at the scale of geological stages. The temporal resolution based on the scale of geological periods does not allow us to capture variations of latitudinal distribution patterns of climate-sensitive lithologic deposits within geological periods, such as the significant movement towards the equator from probability density curves with 


\section{Probability density}

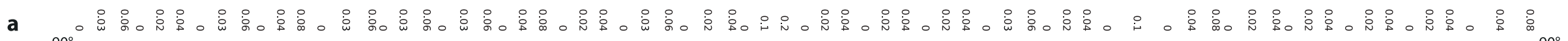

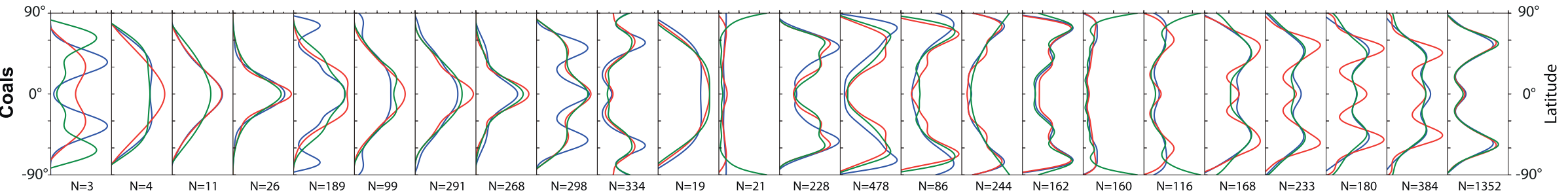

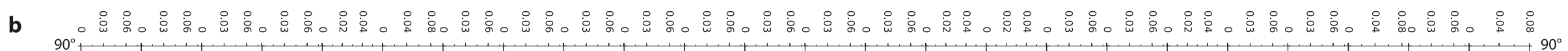

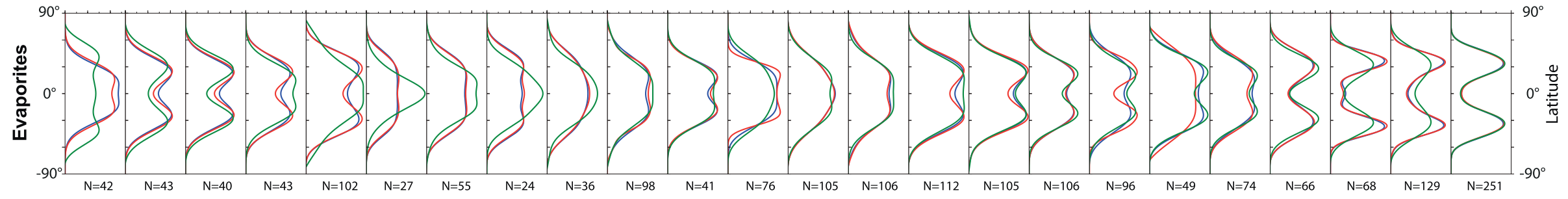

c

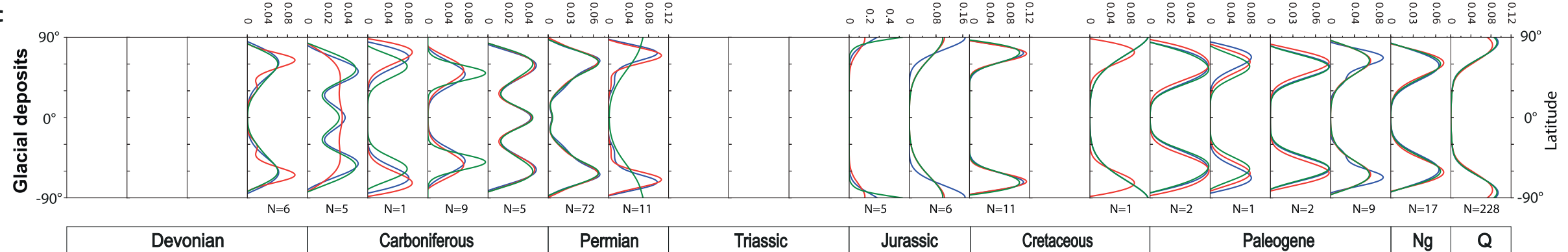

Figure 10. (Colour online) Latitudinal distribution of coals (a), evaporites (b) and glacial deposits (c), for each time interval since the Devonian period, using three reconstruction models (blue: Matthews et al. 2016; red: Scotese, 2008; green: Golonka, 2007). The number of original data points at each time interval is reported at the bottom of each subplot. 


\section{Probability}

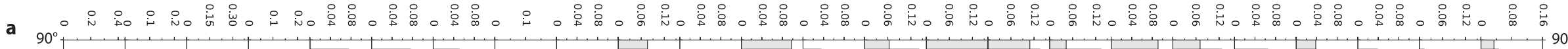

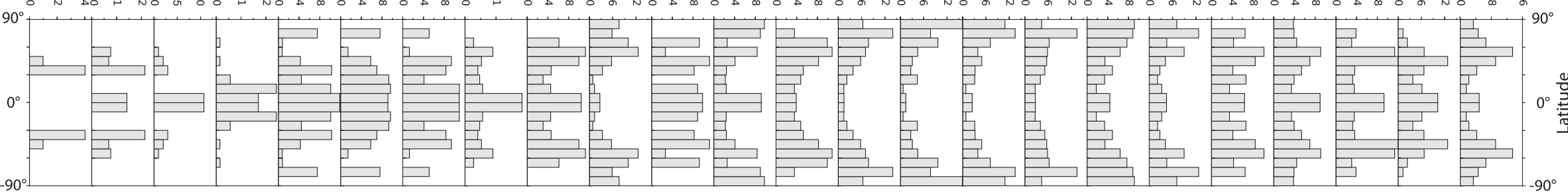

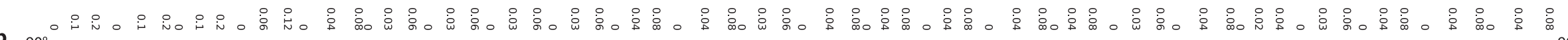
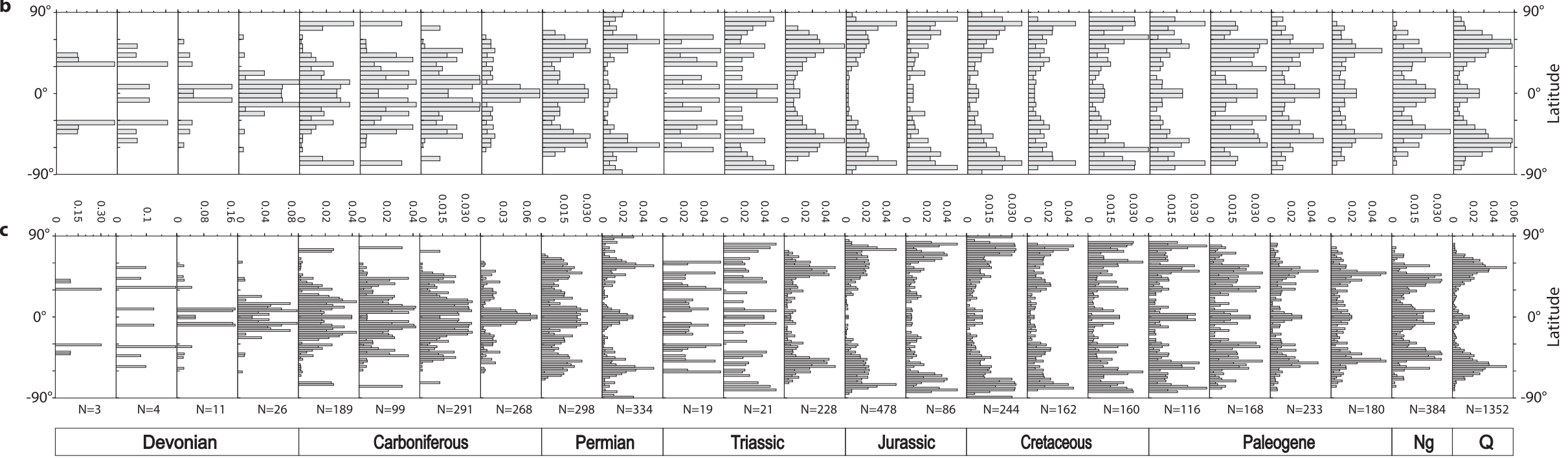

Figure 11. Distribution patterns of coals, reconstructed using the plate motion model of Matthews et al. (2016), for each time interval since the Devonian period using three different bin sizes (red: $10^{\circ}(\mathrm{a})$; blue: $5^{\circ}(\mathrm{b})$; green: $\left.2^{\circ}(\mathrm{c})\right)$ to bin data points to in order to remove the sampling bias. The number of original data points at each time interval is reported at the bottom of each subplot. 

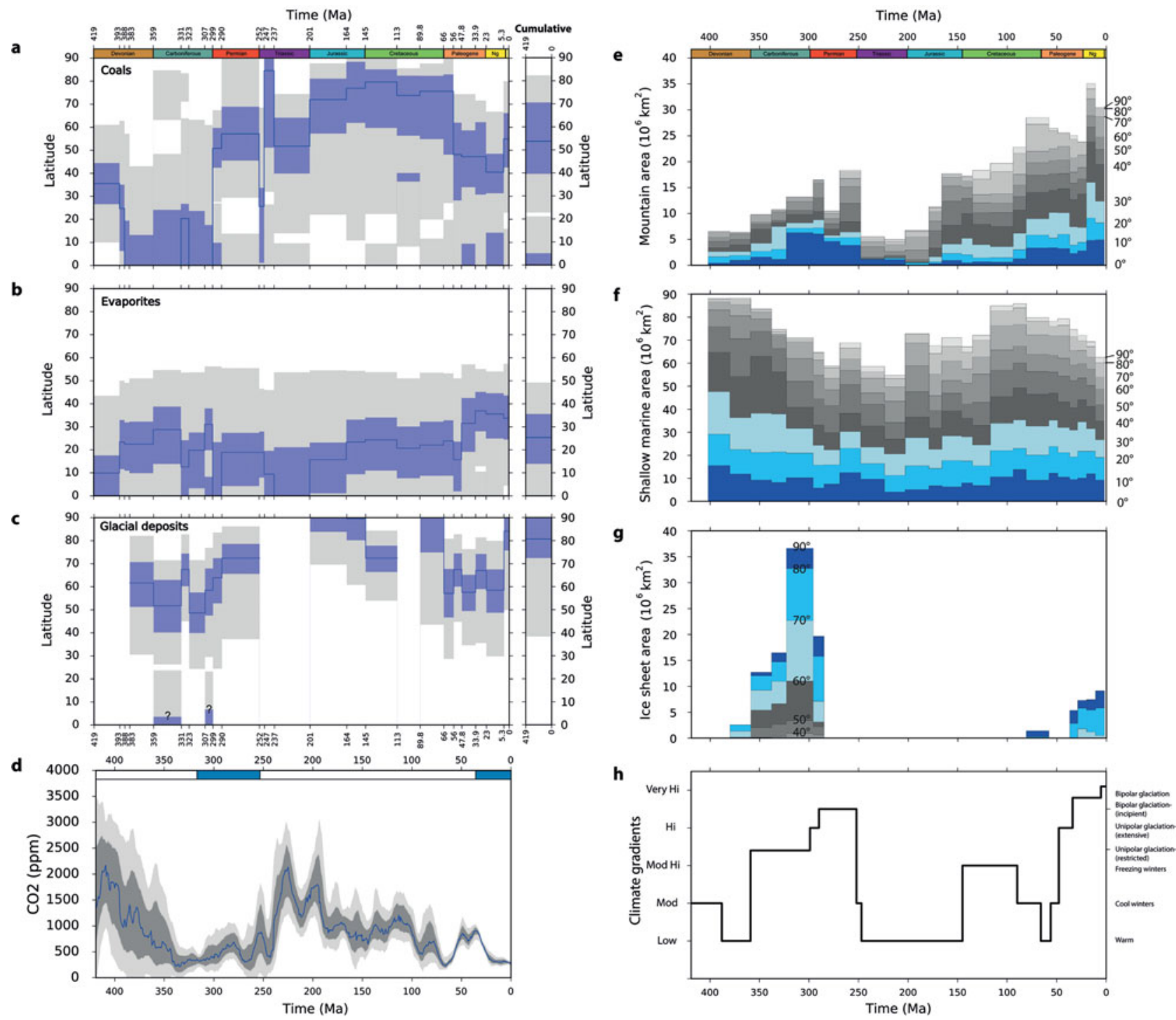

Figure 12. (Colour online) (a, b, c) High-density latitudinal belts of coals, evaporites and glacial deposits, with $50 \%$ (blue area) and $95 \%$ (light grey area) confidence intervals for each time interval since the Devonian period. The blue lines are the most significant peaks of latitudinal distribution. The areas with a question mark indicate records of limited use for climate interpretation. Cumulative high-density probabilities are presented on the rightmost side with bold borders. (d) Atmospheric $\mathrm{CO}_{2}$ concentration curve since the Devonian period, derived from Foster, Royer \& Lunt (2017). $68 \%$ and $95 \%$ confidence intervals are shown as dark and light grey bands. The blue line represents a locally weighted scatterplot smoothing (LOESS) fit, a nonparametric regression fit from Cleveland $\&$ Devlin (1988), through the data. Icehouse intervals and greenhouse intervals (Hay, 2016) are indicated by a blue band and a white band, respectively, at the top of the panel. (e) Global palaeolatitudinal distribution of mountain ranges since the Devonian period calculated from the set of palaeogeographic maps (Golonka et al. 2006; Cao et al. 2017). (f) Global palaeolatitudinal distribution of shallow marine environments (Golonka et al. 2006; Cao et al. 2017). (g) Global palaeolatitudinal distribution of ice sheets from the palaeogeographic maps (Golonka et al. 2006; Cao et al. 2017). (h) Climate temperature gradients since the Early Devonian derived from Boucot, Chen \& Scotese (2013).

$50 \%$ confidence for coals between Early Palaeogene and Middle Palaeogene times in Figure 12a.

Highest-density latitudinal belts of evaporites with $50 \%$ confidence exhibit relatively subtle shifts within a narrow range of latitudes over time (Fig. 12b), although they are very similar to the cumulative result covering the entire temporal range (right panel in Fig. 12b). Evans (2006) suggested that evaporite palaeolatitudes remain stable during Cenozoic-Mesozoic times (a mean palaeolatitude of $23 \pm 4^{\circ}$ ) and during Devonian-Ediacaran times (a mean palaeolatit- ude of $14 \pm 2^{\circ}$ ). This might be because the time division, weighting method or source dataset of Evans (2006) does not capture variations of mean latitudes of evaporites at finer-resolution time divisions. In addition, Evans (2006) argued that the distribution of evaporites over the past 2 billion years has remained bimodal about the equator rather than being centred on the equator as expected from general-circulation climate simulations (Hunt, 1982; Jenkins, 2000, 2001). These considerations are important to test predictions from climate models with differing obliquities. Our 
results generally indicate a bimodal distribution of evaporites over the past $\sim 400 \mathrm{Ma}$, except for Early Devonian, Early Carboniferous (Serpukhovian), earliest Permian (Asselian-Sakmarian) and Middle and Late Jurassic times during which the distribution is unimodal (Fig. 6f). These unimodal distributions should be treated with caution, since comparison with the unsmoothed distributions (Fig. 6e) suggests that the smoothing of the SiZer algorithm contributes to the existence of unimodal distributions in the final results. However, it is also apparent in both the smoothed and unsmoothed results that the clear bimodal pattern observed for the most recent time intervals is not clearly resolved within many older temporal intervals.

\section{5.b. Contributors to the palaeolatitudinal distribution of climate-sensitive lithologies}

The evolution of latitudinal belts of coal samples with $50 \%$ confidence interval (Fig. 12a) may reflect the complex Phanerozoic fluctuations in the latitudinal extent of continental humid zones. The latitudinal distribution of coals with $50 \%$ confidence changes over long timescales (Figs 5, 12a), being concentrated at low latitudes during the Carboniferous period, middle latitudes during Permian and Triassic times, high latitudes during Jurassic - Early Palaeogene times, before returning to middle latitudes during Middle Palaeogene-modern times. The distribution during the Devonian period is unlikely to be reliable due to a lack of data samples (Figs 1,2). The Carboniferous period is significantly different from postPalaeozoic times (Fig. 12a). Abundant coal samples were accumulated in tropical regions $\left(\sim 0-25^{\circ} \mathrm{N}\right.$ and S) during the Carboniferous period, while they were mostly deposited at middle or high latitudes during Mesozoic and Cenozoic times (Fig. 12a). This shift could indicate a climatic transition from humid to arid conditions from the Late Pennsylvanian through the Early Permian on equatorial Pangaea (Rowley et al. 1985; Ziegler, 1990; Parrish, 1993; Ziegler, Hulver \& Rowley, 1997; Tabor \& Montanẽz, 2004; Montanẽz et al. 2007; Tabor et al. 2008; Tabor \& Poulsen, 2008). Tabor \& Poulsen (2008) evaluated the climate factors possibly explaining this climate change, including changing continental configurations from tectonics, time-varying land-sea distribution, supercontinentality, monsoon, uplift/collapse of the Central Pangaean Mountains (CPMs) (Fig. 13), waxing and waning of ice sheets in Gondwanaland and atmospheric $\mathrm{CO}_{2}$. They suggested that the northward drift of most of Pangaea across climate zones, increasing atmospheric $\mathrm{CO}_{2}$ level and Gondwanaland deglaciation could have been the main factors controlling the lowlatitude climate of Pangaea during Late Pennsylvanian - Early Permian times. The deglaciation of Gondwanaland is considered to be a possible cause of climate change over low-latitude Pangaea through its influence on large-scale atmospheric circulation (Zie-

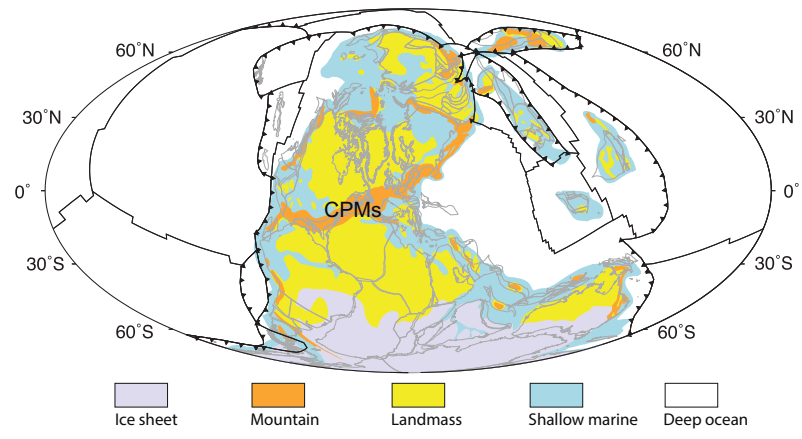

Figure 13. (Colour online) Global palaeogeography in the Late Carboniferous from Cao et al. (2017) showing the location of the Central Pangaean Mountains (CPMs). Black toothed lines indicate subduction zones, and other black lines denote middleocean ridges and transforms. Grey outlines delineate reconstructed present-day coastlines and terranes. Mollweide projection with $0^{\circ} \mathrm{E}$ central meridian.

gler et al. 1987; Perlmutter \& Matthews, 1989; Cecil, 1990; Miller \& West, 1993; Miller, McCahon \& West, 1996; Soreghan, 1997; Cecil et al. 2003; Perlmutter \& Plotnick, 2003; Poulsen et al. 2007). Late Palaeozoic climate simulations suggest that the deglaciation of Gondwana and atmospheric $\mathrm{CO}_{2}$ rise could explain much of the Late Palaeozoic climate change over low-latitude Pangaea, and regional uplift/erosion of the CPMs has a secondary effect on tropical precipitation (Peyser \& Poulsen, 2008). However, the change from dominantly humid palaeoclimate indicators in Pennsylvanian strata to arid and seasonal indicators in Permian strata is considered possibly related to the evolution of the CPMs (Goddéris et al. 2017).

We compared our results to a recent estimate of atmospheric $\mathrm{CO}_{2}$ since the Devonian period (Foster, Royer \& Lunt, 2017; Fig. 12d), and to additional aspects of Earth's palaeogeographic history extracted from digital palaeogeographic reconstructions (Golonka et al. 2006; Cao et al. 2017; Fig. 12e-g). Atmospheric $\mathrm{CO}_{2}$ levels do not indicate significant changes at the beginning of the Permian period that would directly coincide with the poleward shift in coal distributions. The areas of tropical mountain ranges close to the equator (Fig. 12e), thought to be regions of significantly enhanced weathering rates, similarly do not record a significant change from the Late Pennsylvanian through the Early Permian (Fig. 12e). In addition, we computed Phanerozoic ice-sheet areas from palaeogeographic maps (Golonka et al. 2006; Cao et al. 2017), and the results indicate that ice sheets indeed considerably reduced during the Late Pennsylvanian - Early Permian transition (Fig. 12g). Plate tectonic configurations (Golonka, 2007; Scotese, 2008; Matthews et al.2016) indicate that most of Pangaea moved rapidly northward during the Late Pennsylvanian Early Permian transition. Walker, Wilkinson \& Ivany (2002) argued that these motions influenced patterns of shallow-marine carbonates during Phanerozoic times through a long-term decrease in areas of tropical shelf 
based on the palaeogeographic atlas of Scotese \& Golonka (1992), although, a persistent decrease in the area of tropical shallow marine environments over the past $\sim 400 \mathrm{Ma}$ is less apparent in palaeogeographic maps of Golonka et al. (2006) and Cao et al. (2017) (Fig. 12f). The resulting migration of tropical basins from humid climate zones associated with the Intertropical Convergence Zone into the adjacent northern subtropical zone could be attributed to long-term tropical aridification (Ziegler et al. 1977; Witzke, 1990; Gibbs et al. 2002; Rees et al. 2002; Tabor et al. 2008).

It is important to consider some non-climatic factors that may influence the latitudinal distributions of these lithologies. Carboniferous coal-forming flora were dominated by pteridophytes with a low tolerance to groundwater fluctuations due to their shallow root system, making them less likely to form thick preserved coal seams even where favourable peat-forming conditions existed (Diessel, 1992). In contrast, postCarboniferous coal measures were dominated by Gymnosperms from the Permian to the Cretaceous and angiosperms since the Triassic. They can occupy a wider range of latitudes due to their greater tolerance to groundwater fluctuations and adaptability in more fully marginal peat-forming conditions (Diessel, 1992). The evolution of plant groups through space and time could contribute to the changing distributions of coal deposits through time, especially its significant poleward shift in the Early Permian. Additionally, a further contributor to the Carboniferous lowlatitude peak in coal distribution could be the relatively rare occurrence of extensive foreland-basin systems within the tropics during Pangaea assembly, ideal for the formation and preservation of coal (Nelsen et al. 2016). In summary, the major poleward shift in coal distributions beginning in the Early Permian is likely to be driven by a combination of processes, resulting from the interplay of tectonics, deglaciation, evolution of plants and palaeoclimate.

The changing latitudinal belts of evaporites with $50 \%$ confidence (Fig. 12b) indicate the evolution of low-latitudinal arid zones over time, but the fluctuations are subtle relative to other indicators. During the Early Palaeogene, they underwent a relatively rapid shift away from the equator, contemporaneous with climate-driven shifts in coals and glacial deposits. In older times, the origins of changes are less clear (Fig. 12b). Ancient marine evaporite formation is not only related to dry climate but also tectonic setting (Warren, 2010). For instance, during the Early Devonian, many evaporites occurred in the northern margins of tropical Laurentia and low-latitude Siberia (Fig. 1), which could explain the equatorial distribution of evaporites during the time (Fig. 12b). The latitudinal belt of evaporites shifts poleward to mean latitudes of $\sim 25^{\circ} \mathrm{N}$ and $\mathrm{S}$ during Middle Devonian Early Carboniferous time (Fig. 12b). This could be mostly due to evaporites accumulating in the southern, western or eastern margins of Laurentia during the Middle Devonian - Early Carboniferous time (Fig. 1).
From the assembly of Pangaea in the Late Carboniferous until the Middle Triassic (Ziegler et al. 1979), abundant evaporites occur in the western and eastern margins of low-latitude Pangaea (Fig. 1). Starting from the Late Triassic ( $\sim 240 \mathrm{Ma})$ the pattern of rift basins formed during Pangaea break-up (notably the Atlantic margins and the Gulf of Mexico) will have exerted an additional control on evaporite distributions (Fig. 1).

Atmospheric $\mathrm{CO}_{2}$ is thought to be a primary driver of both ice-sheet and climate variability (Montañez \& Poulsen, 2013; Lowry et al. 2014; Foster, Royer $\&$ Lunt, 2017), and solar luminosity secondarily influences Palaeozoic glaciation (Lowry et al. 2014). Mountain uplift enhances silicate rock weathering, resulting in a decrease in atmospheric $\mathrm{CO}_{2}$ concentrations (Kump \& Arthur, 1997; Berner, 2004; Montañez \& Poulsen, 2013; Foster, Royer \& Lunt, 2017). The latitudinal distribution patterns of glacial deposits reported in this study (Fig. 12c) record three major Phanerozoic glacial periods, during Carboniferous-Permian, Late Jurassic - early Cretaceous and Cenozoic times (Frakes, Francis \& Syktus, 1992). The late Palaeozoic icehouse is the longest-lived ice age of the Phanerozoic (Montañez \& Poulsen, 2013). Ice sheets were abundant over the South Pole during this period. This ice age corresponds to intense mountain uplift around tropical Pangaea (Fig. 12e) which could have contributed to late Palaeozoic cooling through enhanced silicate weathering (Kump et al. 1999; Godderis et al. 2017). The high temperature gradients during the time, derived from the comprehensive global-scale compilation of lithologies (Boucot \& Gray, 2001; Boucot, Chen \& Scotese, 2013), also indicate a cooling (Fig. 12h). The Cenozoic glaciation corresponds to remarkable topographic uplift (Fig. 12e) of the Himalaya - Tibetan Plateau (Molnar \& England, 1990) contributing to atmospheric $\mathrm{CO}_{2}$ decrease through enhanced silicate weathering and resulting high temperature gradients (Fig. 12h). Therefore, our results suggest that mountain uplift could have been an important factor in the two major ice ages in late Palaeozoic and Cenozoic times through decreased atmospheric $\mathrm{CO}_{2}$ and enhanced temperature gradients. Yet, other factors including organic carbon burial and outgassing through volcanism and metamorphism (e.g. Pearson \& Palmer, 2000) might also contribute to the drawdown of atmospheric $\mathrm{CO}_{2}$.

\section{5.c. Workflow limitations}

The presented workflow uses a $5^{\circ} \times 5^{\circ}$ grid of Earth's surface to bin lithology data points. By resampling the data points, we removed the spatial sampling bias. However, latitude strips at or near the equator have larger areas than the polar ones (see fig. 1 in Vilhena \& Smith, 2013), which leads to over-binning in high-latitude strips. Ideally, an equal-area gridding scheme would be created to correct spatial sampling bias in the dataset (Vilhena \& Smith, 2013), and this 
could be considered in future work. However, we used the simpler $5^{\circ} \times 5^{\circ}$ binning so that our results are comparable to the previous study of Ziegler et al. (2003).

There is also a temporal sampling bias in the workflow. The reconstruction ages used to construct the climatically sensitive lithologic data to ancient geographic locations represent discrete time periods of several millions of years. Because the reconstructed palaeogeographic locations of the lithologic data points change within the time range for which their age is assigned in the source data, sample locations are not truly defined by one point palaeolocation, and could be represented by an average location over a given time period in future work. Providing a continuous representation of palaeolatitudinal distribution patterns indicated from palaeoclimate lithologic data remains an important challenge. The temporal resolution in this study does not allow us to capture some short-term fluctuations which may be interpreted from more detailed records (e.g. Horton, Poulsen \& Pollard, 2010; Montanẽz et al. 2016). For instance, our workflow considers the time interval 290-252 Ma during the Permian period as a single stage, and cannot reflect the fluctuations indicated from atmospheric $\mathrm{CO}_{2}$ level during that time (Fig. 12a, d). Higher temporal resolution would make it possible to refine climate reconstructions.

A further improvement to our analysis could be to use palaeogeographic maps rather than continental polygons to correct for the bias due to the uneven distribution of areas through time over the lithologic data. Such maps have the potential to provide a clearer definition of which areas within the continental polygons used here are likely to host certain types of lithologies associated specifically with shallow marine or terrestrial environments. However, such palaeogeographic maps (e.g. Ronov, Khain \& Seslavinsky, 1984); Ronov, Khain \& Balukhovsky, 1989); Scotese, 2001, 2004; Golonka et al. 2006; Blakey, 2008; Cao et al. 2017) are more interpretive than continental polygons and typically do not use divisions of the geological timescale that are exactly consistent either with each other or with the time range definitions of the lithologic data considered here, and remains an outstanding problem in terms of how to obtain palaeogeographic maps and lithologies at the same temporal resolution.

\section{Conclusions}

This study provides a framework to investigate the shifting climatic zones through deep geological time by using plate reconstructions, a comprehensive database and new data analysis approaches. We quantified the palaeolatitudinal zonal patterns of climatelithologic deposits of coals, evaporites and glacial deposits since the Devonian, with corrections for sampling- and area-biases, and used statistical methods (SiZer and HDR) to obtain probability dens- ity functions and estimate high-probability latitudinal belts. The sensitivity test of the latitudinal distributions of climate-sensitive lithologic deposits on uneven distribution of continental areas through time indicates that these climate indicators are sensitive to the correction of continental areas, and that the distribution of coals is more sensitive than evaporites and glacial deposits to this correction, particularly in Middle Devonian, Carboniferous, Early and Middle Triassic, Jurassic, Cretaceous and Early Palaeogene times. The latitudinal distributions of these lithologic indicators do not show strong sensitivity to the reconstruction model.

The distribution of coal palaeolatitudes herein, with higher temporal resolution than previous studies, shifted to significantly higher latitudes at the beginning of the Permian, contrasting with the previous suggestion that the shift started in the Carboniferous (Diessel, 1992). The changing distribution of coals over the period from the Permian to the present also cannot be considered to have been constant as proposed by Ziegler et al. (2003). Our results indicate a clearly bimodal distribution of evaporites over the past $\sim 400 \mathrm{Ma}$, except for the Early Devonian, Early Carboniferous, the earliest Permian and Middle and Late Jurassic (Fig. 6f). This suggests that the previously proposed bimodal or unimodal evaporite patterns could have alternated over geological times. The distribution of glacial deposits is consistent with previous interpretations of the main icehouse and greenhouse periods during the last $\sim 400 \mathrm{Ma}$.

We considered some of the main factors controlling the latitudinal distributions of the lithologic deposits over time. There is no single factor that dominates the changing distributions from the Early Devonian to the present. As many previous studies have noted, tectonic factors associated with Pangaea assembly and breakup and the waxing and waning of ice sheets in Gondwanaland could have been significant factors influencing the distributions of the lithologies, including the extent of tropical continental humid zones from the Late Pennsylvanian through the Early Permian. The evolution of plant groups through space and time has influenced coal distributions, especially in a significant poleward shift during the Early Permian due to the rise of Gymnosperms. Due to these many factors, care should be taken when using the latitudinal distribution of these lithologies to constrain both past global climate and the past positions of continents.

Acknowledgements. This work is supported by Australian Research Council (ARC) grants IH130200012 (R.D.M., S.Z., S.W.) and ARC DE160101020 (N.F.). W. Cao was also supported by a University of Sydney International Scholarship (USydIS). This work also benefited from support of the Alfred P. Sloan Foundation (G-2017-9997) and the Deep Carbon Observatory (DCO). We thank John Cannon and Michael Chin for help with GPlates and pyGPlates, and Sally Cripps, Rohitash Chandra, Rob Hyndman, Stephen Marron and Maelis Arnould for assistance with programming. 


\section{Supplementary material}

To view supplementary material for this article, please visit https://doi.org/10.1017/S0016756818000110

\section{References}

Becq-Giraudon, J. F., Montenat, V. \& Van Den DRIESSCHE, J. 1996. Hercynian high-altitude phenomena in the French Massif Central: tectonic implications. Palaeogeography, Palaeoclimatology, Palaeoecology 122, 227-40.

Berner, R. A. 2004. The Phanerozoic Carbon Cycle: CO2 and O2. New York: Oxford University Press, $150 \mathrm{pp}$.

BlakeY, R. C. 2008. Gondwana paleogeography from assembly to breakup - A 500 m.y. odyssey. In Resolving the Late Paleozoic Ice Age in Time and Space (eds C.R. Fielding, T.D. Frank \& J.L. Isbell), pp. 1-28. Geological Society of America Special Paper no. 441.

Boucot, A. J., Chen, X. \& Scotese, C. R. 2013. Phanerozoic Paleoclimate: An Atlas of Lithologic Indicators of Climate. SEPM, Concepts in Sedimentology and Paleontology vol. 11, $478 \mathrm{pp}$.

Boucot, A. J. \& GraY, J. 2001. A critique of Phanerozoic climatic models involving changes in the $\mathrm{CO}_{2}$ content of the atmosphere. Earth-Science Reviews 56(1-4), 1159.

Brandley, R. T. \& Krause, F. F. 1993a. Carbonate and siliciclastic deposition on a wave swept, cold-water, lowlatitude ramp: Lower Carboniferous Mount Head Formation, southwestern Alberta, Canada. Canadian Society of Petroleum Geologists, Annual Convention, Program and Abstracts, Carboniferous to Jurassic Pangea, $35 \mathrm{pp}$.

Brandley, R. T. \& Krause, F. F. 1993b. Thinolite-type pseudomorphs of ikaite: cold water indicators in the Mt. Head (Early Carboniferous-Visean), Rocky Mountains, Canada. Canadian Society of Petroleum Geologists, Annual Convention, Program and Abstracts, Carboniferous to Jurassic Pangea, $34 \mathrm{pp}$.

Brandley, R. T. \& Krause, F. F. 1994. Thinolite-type pseudomorphs after ikaite: indicators of cold water on the subequatorial western margin of Lower Carboniferous North America. In Pangea: Global Environments and Resources (eds V. Embry, B. Beauchamp \& D.J. Glass), pp. 333-44. Canadian Society of Petroleum Geologists Memoir no. 17.

CaO, W., Zahirovic, S., Flament, N., Williams, S., GolONKA, J. \& MülleR, R. D. 2017. Improving global paleogeography since the late Paleozoic using paleobiology. Biogeosciences 14, 5425-39.

Cecil, C. B. 1990. Palaeoclimate controls on stratigraphic repetition of chemical and siliciclastic rocks. Geology 18, 533-6.

Cecil，C. B., Dulong, F. T., West, R. R., Stamm, R., Wardlaw, B. \& Edgar, N. T. 2003. Climate controls on the stratigraphy of a middle Pennsylvanian cyclothem in North America. In Climate Controls on Stratigraphy (eds C. B. Cecil \& T. N. Edgar), pp. 151-80. Society of Economic Paleontologists and Mineralogists Special Publication no. 77.

Chaudhuri, P. \& Marron, J. S. 1999. SiZer for exploration of structure in curves. Journal of the American Statistical Association 94(447), 807-23.

Cleveland, W. S. \& Devlin, S. J. 1988. Locally weighted regression: an approach to regression analysis by local fitting. Journal of the American Statistical Association 83, 596-610.
Craggs, H. J., Valdes, P. J. \& Widdowson, M. 2011. Climate model predictions for the latest Cretaceous: an evaluation using climatically sensitive sediments as proxy indicators. Palaeogeography, Palaeoclimatology, Palaeoecology 315-316, 12-23.

Diessel, C. F. K. 1992. Coal-Bearing Depositional Systems. Berlin: Springer-Verlag, $72 \mathrm{pp}$.

DomeIER, M. \& TorsviK, T. H. 2014. Plate tectonics in the late Paleozoic. Geoscience Frontiers 5(3), 303-50.

Evans, D. A. D. 2006. Proterozoic low orbital obliquity and axial-dipolar geomagnetic field from evaporite palaeolatitudes. Nature 444(7115), 51-5.

Foster, G. L., Royer, D. L. \& Lunt, D. J. 2017. Future climate forcing potentially without precedent in the last 420 million years. Nature Communications 8, 14845. doi: $10.1038 /$ ncomms 14845 .

Frakes, L. A., Francis, J. E. \& Syktus, J. I. 1992. Climate Modes of the Phanerozoic. Cambridge: Cambridge University Press.

Gibbs, M. T., Rees, P. M., Kutzbach, J. E., Ziegler, A. M., Behling, P. J. \& Rowley, D. B. 2002. Simulations of Permian climate and comparisons with climatesensitive sediments. The Journal of Geology 110, 3355 .

Godderis, Y., Donnadieu, Y., Carretier, S., Aretz, M., Dera, G., Macouin, M. \& Regard, V. 2017. Onset and ending of the late Palaeozoic ice age triggered by tectonically paced rock weathering. Nature Geoscience $\mathbf{1 0}$, 382-6.

Golonka, J. 2007. Late Triassic and Early Jurassic palaeogeography of the world. Palaeogeography, Palaeoclimatology, Palaeoecology 244(1-4), 297-307.

Golonka, J., Krobicki, M., PajaK, J., Giang, N. V. \& Zuchiewicz, W. 2006. Global Plate Tectonics and Paleogeography of Southeast Asia. Kraków: Faculty of Geology, Geophysics and Environmental Protection, AGH University of Science and Technology, $128 \mathrm{pp}$.

Gordon, W. A. 1975. Distribution by latitude of Phanerozoic evaporite deposits. The Journal of Geology 83(6), 671-84.

Hallam, A. 1985. A review of Mesozoic climates. Journal of the Geological Society 142(8), 433-45.

HaY, W. W. 2016. Experimenting on a Small Planet: A History of Scientific Discoveries, a Future of Climate Change and Global Warming, 2nd edn. New York: Springer, 819 pp..

Horton, D. E., Poulsen, C. J. \& Pollard, D. 2010. Influence of high-latitude vegetation feedbacks on late Paleozoic glacial cycles. Nature Geoscience 3, $572-7$.

Hunt, B. G. 1982. The impact of large variations of the Earth's obliquity on the climate. Journal of the Meteorological Society of Japan 60, 309-18.

Hyndman, R. J. 1996. Computing and graphing highest density. The American Statistician 50(2), 120-6.

JENKINS, G. S. 2000. Global climate model high-obliquity solutions to the ancient climate puzzles of the Faint Young Sun Paradox and low-altitude Proterozoic Glaciation. Journal of Geophysical Research 105, 7357-70.

JENkINS, G. S. 2001. High-obliquity simulations for the Archean Earth: implications for climatic conditions on early Mars. Journal of Geophysical Research 106, 32903-13.

Kump, L. R. \& Arthur, M. A. 1997. Global chemical erosion during the Cenozoic: weatherability balances the budgets. In Tectonic Uplift and Climate Change (ed. W. F. Ruddiman), pp. 399-426. New York: Plenum Press. 
Kump, L. R., Arthur, M. A., Patzkowsky, M. E., Gibbs, M. T., Pinkus, D. S. \& Sheehan, P. M. 1999. A weathering hypothesis for glaciation at high atmospheric $\mathrm{pCO}_{2}$ during the Late Ordovician. $\mathrm{Pa}$ laeogeography, Palaeoclimatology, Palaeoecology 152, 173-87.

Lowry, D. P., Poulsen, C. J., Horton, D. E., TorsviK, T. H. \& Pollard, D. 2014. Thresholds for Paleozoic ice sheet initiation. Geology 42, 627-30.

Matthews, K. J., Maloney, K. T., Zahirovic, S., Williams, S. E., Seton, M. \& Müller, R. D. 2016. Global plate boundary evolution and kinematics since the late Paleozoic. Global and Planetary Change 146, 226-50.

McCabe, P. J. \& Parrish, J. T. 1992. Tectonic and climatic controls on the distribution and quality of Cretaceous coals. In Controls on the Distribution and Quality of Cretaceous Coals. (eds P. J. McCabe \& J. T. Parrish), pp. 1-15. Geological Society of America Special Paper no. 267.

Miller, K. B., McCahon, T. J. \& West, R. R. 1996. Lower Permian (Wolfcampian) palaeosol-bearing cycles of the U.S. Midcontinent: evidence of climatic cyclicity. Journal of Sedimentary Research 66, 71-84.

MilleR, K. B. \& West, R. R. 1993. A reevaluaation of Wolfcampian cyclothems in northeastern Kansas: significance of subaerial exposure and flooding surfaces. Kansas Geological Survey Bulletin 235, 1-26.

Molnar, P. \& England, P. 1990. Late Cenozoic uplift of mountain ranges and global climatic change: chicken or egg? Nature 346, 29-34.

Montañez, I. P., McElwain, J. C., Poulsen, C. J., White, J. D., DiMichele, W. A., Wilson, J. P., Griggs, G. \& Hren, M. T. 2016. Climate, $p \mathrm{CO}_{2}$ and terrestrial carbon cycle linkages during late Palaeozoic glacialinterglacial cycles. Nature Geoscience 9, 824-8.

Montañez, I. P. \& Poulsen, C. J. 2013. The Late Paleozoic Ice Age: an evolving paradigm. Annual Review of Earth and Planetary Sciences 41(1), 629-56.

Montañez, I. P., Tabor, N. J., Niemeier, D., DiMichele, W. A., Frank, T. D., Fielding, C. R. \& Isbell, J. L. 2007. $\mathrm{CO}_{2}$-forced climate and vegetation instability during Late Palaeozoic deglaciation. Science 315, 8791.

Müller, R. D., Royer, J. Y. \& Lawver, L. A. 1993. Revised plate motions relative to the hotspots from combined Atlantic and Indian Ocean hotspot tracks. Geo$\log y$ 21(3), 275-8.

Müller, R. D., Seton, M., Zahirovic, S., Williams, S. E., Matthews, K. J., Wright, N. M., Shephard, G. E., Maloney, K. T., BarnetT-Moore, N., Bower, D. J. \& CANNON, J. S. 2016. Ocean basin evolution and globalscale reorganization events since Pangea breakup. $A n$ nual Review of Earth and Planetary Science Letters 44, 107-38.

Nelsen, M. P., DiMichele, W. A., Peters, S. E. \& Boyce, C. K. 2016. Delayed fungal evolution did not cause the Paleozoic peak in coal production. Proceedings of the National Academy of Sciences 113(9), 2442-7.

PARrish, J. T. 1993. Climate of the supercontinent Pangaea. The Journal of Geology 101, 215-33.

Parrish, J. T., Ziegler, A. M. \& Scotese, C. R. 1982. Rainfall patterns and the distribution of coals and evaporites in the Mesozoic and Cenozoic. Palaeogeography, $\mathrm{Pa}$ laeoclimatology, Palaeoecology 40(1-3), 31-66.

Pearson, P. N. \& Palmer, M.R. 2000. Atmospheric carbon dioxide concentrations over the past 60 million years. Nature 406, 695-9.
Perlmutter, M. A. \& Matthews, M. D. 1989. Global cyclostratigraphy - a model. In Quantitative Dynamic Stratigraphy (ed. T. A. Cross), pp. 223-60. Englewood Cliffs, New Jersey: Prentice Hall.

Perlmutter, M. A. \& Plotnick, R. E. 2003. Hemispheric asymmetry of the marine stratigraphic record: conceptual proof of a unipolar ice cap. In Climate Controls on Stratigraphy (eds C. B. Cecil \& T. N. Edgar), Society of Economic Paleontologists and Mineralogists Special Publication, vol. 77, pp. 51-66.

Peyser, C. E. \& Poulsen, C. J. 2008. Controls on PermoCarboniferous precipitation over tropical Pangaea: a GCM sensitivity study. Palaeogeography, Palaeoclimatology, Palaeoecology 268(3-4), 181-92.

Poulsen, C. J., Pollard, D., Montañez, I. P. \& Rowley, D. 2007. Late Palaeozoic tropical climate response to Gondwana deglaciation. Geology 35, 771-4.

Price, G. D., Sellwood, B. W. \& Valdes, P. J. 1995. Sedimentological evalaution of general circulation model calculations for the 'greenhouse' Earth: Cretaceous and Jurrassic case studies. Sedimentary Geology 100, 159 80.

Rees, P. M., Ziegler, A. M., Gibbs, M. T., Kutzbach, J. E., Behling, P. J. \& Rowley, D. B. 2002. Permian phytogeographic patterns and climate data/model comparisons. The Journal of Geology 110, 1-31.

Ronov, A., Khain, V. \& Balukhovsky, A. 1989. Atlas of Lithological-Paleogeographical Maps of the World, Mesozoic and Cenozoic of Continents and Oceans. Leningrad: USSR Academy of Sciences, $77 \mathrm{pp}$.

Ronov, A., Khain, V. \& Seslavinsky, K. 1984. Atlas of Lithological-Paleogeographical Maps of the World, Late Precambrian and Paleozoic of Continents. Leningrad: USSR Academy of Sciences, $70 \mathrm{pp}$.

Rowley, D. B., Raymond, A., Parrish, J. T., Lottes, A. L., Scotese, C. R. \& Ziegler, A. M. 1985. Carboniferous palaeogeographic, phytogeographic, and palaeoclimatic reconstructions. International Journal of Coal Geology $5,7-42$.

Scotese, C. R. 2001. Atlas of Earth History, Volume 1: Paleogeography. Arlington, Texas: PALEOMAP Project, $52 \mathrm{pp}$.

ScoteSE, C. R. 2004. A Continental Drift flipbook. The Journal of Geology 112(6), 729-41.

Scotese, C. R. 2008. The PALEOMAP Project PaleoAtlas for ArcGIS, Volume 2: Cretaceous Paleogeographic and Plate Tectonic Reconstructions. Arlington, Texas: PALEOMAP Project.

Scotese, C. R. \& BARRetT, S. F. 1990. Gondwana's movement over the South Pole during the Palaeozoic: evidence from lithological indicators of climate. In $\mathrm{Pa}$ laeozoic Palaeogeography and Biogeography (eds W. S. McKerrow \& C. R. Scotese). Geological Society of London, Memoir no. 12, 75-85.

Scotese, C. R. \& Golonka, J. 1992. Paleogeographic Atlas. PALEOMAP Progress Report 20-0692. Arlington: Department of Geology, University of Texas, $34 \mathrm{pp}$.

SOREGHAN, G. S. 1997. Walther's Law, climate change, and Upper Paleozoic cyclostratigraphy in the Ancestral Rocky Mountains. Geology 67, 1001-4.

Swanson-Hysell, N. L. \& Mac Donald, F. A. 2017. Tropical weathering of the Taconic orogeny as a driver for Ordovician cooling. Geology 45(8), 719-22.

Tabor, N. J. \& MontañEz, I. P. 2004. Permo-Pennsylvanian alluvial palaeosols (north-central Texas): highresolution indicator records of the evolution of early Pangaean palaeoclimate. Sedimentology 51, 851-84. 
Tabor, N. J., Montañez, I. P., Scotese, C. R., Poulsen, C. J. \& MACK, G. H. 2008. Paleosol archives of environmental and climatic history in paleotropical western Pangea during the latest Pennsylvanian through Early Permian. In Resolving the Late Paleozoic Ice Age in Time and Space (eds C. R. Fielding, T. D. Frank \& J. L. Isbell), pp. 291-303. Geological Society of America Special Paper no. 441.

Tabor, N. J. \& Poulsen, C. J. 2008. Palaeoclimate across the Late Pennsylvanian-Early Permian tropical palaeolatitudes: a review of climate indicators, their distribution, and relation to palaeophysiographic climate factors. Palaeogeography, Palaeoclimatology, Palaeoecology 268(3-4), 293-310.

van Hinsbergen, D. J. J., De Groot, L. V., van Schaik, S. J., Spakman, W., BiJl, P. K., SluiJs, A., Langereis, C. G. \& Brinkhuis, H. 2015. A paleolatitude calculator for paleoclimate studies. PLOS ONE 10(6), $1-21$.

Vilhena, D. A. \& Smith, A. B. 2013. Spatial bias in the marine fossil record. PLOS ONE 8(10), e74470. doi: 10.137.1/journal.pone.0074470.

Walker, L. J., Wilkinson, B. H. \& Ivany, L. C. 2002. Continental drift and Phanerozoic carbonate accumulation in shallow shelf and deep marine settings. The Journal of Geology 110, 75-88.

WARREN, J. K. 2010. Evaporites through time: tectonic, climatic and eustatic controls in marine and nonmarine deposits. Earth-Science Reviews 98 217-68.

WitZKE, B. J. 1990. Palaeoclimatic constraints for palaeozoic Palaeolatitudes of Laurentia and Euramerica. In Palaeozoic Palaeogeography and Biogeography (eds W. S. McKerrow \& C. R. Scotese), pp. 57-73. Geological Society of London Memoir no. 12.

Wright, N., Zahirovic, S., Müller, R. D. \& Seton, M. 2013. Towards community-driven paleogeographic reconstructions: integrating open-access paleogeographic and paleobiology data with plate tectonics. Biogeosciences 10(3), 1529-41.

ZIEGLER, A. M. 1990. Phytogeographic patterns and continental configurations during the Permian Period. In $\mathrm{Pa}$ laeozoic Palaeogeography and Biogeography (eds W. S. McKerrow \& C. R. Scotese),. Geological Society of London Memoir no. 12, pp. 363-79.
Ziegler, A. M., Eshel, G., McAllister Rees, P., Rothfus, T. A., Rowley, D. B. \& Sunderlin, D. 2003. Tracing the tropics across land and sea: Permian to present. Lethaia 36, 227-54.

Ziegler, A. M., Hansen, K. S., Johnson, M. E., Kelly, M. A., Scotese, C. R. \& VAN DeR Voo, R. 1977. Silurian continental distribution, palaeogeography, climatology, and biogeography. Tectonophysics 40, 13-51.

Ziegler, A. M., Hulver, M. L. \& Rowley, D. B. 1997. Permian world topography and climate. In Late Glacial and Post-Glacial Environmental Changes - Quaternary, Carboniferous-Permian and Proterozoic (ed. I. P. Martini), pp. 111-46. Oxford: Oxford University Press.

Ziegler, A. M., Raymond, A., Geirlowski, T. C., Horrell, M. A., Rowley, D. B. \& Lottes, A. L. 1987. Coal, climate and terrestrial productivity: the present and early Cretaceous compared. In, Coal and Coal-bearing Strata: Recent Advances (ed. A. C. Scott). Geological Society of London Special Paper no. 32, pp. 25-49.

Ziegler, A. M., Scotese, C. R. \& Barrett, S. F. 1983. Mesozoic and Cenozoic paleogeographic maps. In Tidal Friction and the Earth's Rotation II: Proceedings of a Workshop Held at the Centre for Interdisciplinary Research (ZiF) of the University of Bielefeld, 28 September-3 October 1981 (eds P. Brosche \& J. Sündermann), pp. 240-52. Berlin: Springer Verlag.

Ziegler, A. M., Scotese, C. R., McKerrow, W. S., Johnson, M. E. \& Bambach, R.K. 1979. Paleozoic paleogeography. Annual Review of Earth and Planetary Sciences 7, 473-502.

\section{Appendix: Software availability}

SiZer analysis is performed in MatLab using the 'Smoothing' package (Chaudhuri \& Marron, 1999) available at http:// www.stat.unc.edu/faculty/marron/marron_software.html. SiZer can also be found in the package 'feature' (version 1.2.13) in ' $R$ ' statistical software (version 3.3.2). HDR from Hyndman (1996) is performed using the 'hdrcde' package (version 3.1) in ' $R$ ' statistical software (version 3.3.2). The HEALPix method is conducted using the library 'healpy' (version 1.10.3) in Python 2.0 and its documentation is available at http://healpy. readthedocs.io/en/latest/index.html. 